\title{
Do Provisional Estimates of Output Miss Economic Turning Points?
}

\author{
Karen E. Dynan \\ Stop 93 \\ Federal Reserve Board \\ Washington, DC 20551 \\ (202)-452-2553 \\ kdynan@frb.gov
}

\author{
Douglas W. Elmendorf \\ Stop 80 \\ Federal Reserve Board \\ Washington, DC 20551 \\ (202)-452-3623 \\ delmendorf@frb.gov
}

November 2001

\begin{abstract}
Initial estimates of aggregate output and its components are based on very incomplete source data, so they may not fully capture shifts in economic conditions. In particular, if those estimates are based partly on trends in preceding quarters, one would expect to see provisional estimates overstating activity when actual output is decelerating and understating it when actual output is accelerating. We examine this issue using the Real Time Data Set for Macroeconomists, which contains contemporaneous estimates of GNP or GDP and its components beginning in the late 1960s, as well as financial-market information and other data. Our results indicate that provisional estimates do not fully capture accelerations and decelerations, suggesting some tendency for provisional estimates to miss economic turning points. We also consider the related question of whether better use of contemporaneous data could improve the quality of provisional estimates. We find that provisional estimates do not represent optimal forecasts of the current estimates, but that the improvement in forecast quality from including additional contemporaneous data appears to be quite small.
\end{abstract}

We are grateful to Shital Patel for research assistance and to Darrel Cohen, Bruce Fallick, Dennis Fixler, Bruce Grimm, Spencer Krane, David Lebow, Andreas Lehnert, Athanasios Orphanides, Dan Sichel, Sandy Struckmeyer, and Joyce Zickler for helpful comments. The views expressed here are our own and not necessarily those of the Federal Reserve Board or other members of its staff. 
Initial estimates of aggregate output and its components are based on very incomplete source data, so they may not fully capture shifts in economic conditions. Consider, for example, the onset of the 1990-91 recession. When the Federal Open Market Committee (FOMC) met in November 1990 to set monetary policy, aggregate output was estimated to have risen at annualized rates of 1.7 percent, 0.4 percent, and 1.8 percent respectively in the first three quarters of the year. These figures suggested an economy that was muddling through a period of slow but positive growth, and, indeed, the transcript of the FOMC meeting reveals uncertainty about whether the economy was entering a recession. Yet, the business-cycle peak was identified by the National Bureau of Economic Research in April 1991 as having occurred in July 1990. Moreover, after more than half a dozen revisions, the data show a clear deceleration in economic activity during 1990 - from a 5.1 percent first-quarter increase to a 0.9 percent second-quarter gain and then a 0.7 percent third-quarter decline.

In this paper we explore whether provisional estimates of GDP (or GNP in earlier years) systematically miss turning points in the economy. ${ }^{1}$ In particular, because those estimates are based partly on trends in preceding quarters, one would expect to see provisional estimates overstating activity when GDP is decelerating and understating it when GDP is accelerating. We find that this hypothesis is supported by the evidence. The related question of whether better use of contemporaneous data could improve the quality of provisional estimates yields a mixed answer: provisional estimates do not represent optimal forecasts of the current estimates, but the improvement in forecast quality from including additional data appears to be quite small.

The first section of the paper summarizes the revision process for the National Income and Product Accounts (NIPA) and presents summary statistics on the revisions. Nearly one month after the end of a calendar quarter, the U.S. government releases its first official estimate of GDP growth during that quarter, the so-called "advance" estimate. That estimate is revised one month later, and again one month after that; subsequently, it is revised several more times in the annual revisions to the NIPA that typically occur every summer, and in so-

1. We focus on the measure of aggregate output emphasized by the Bureau of Economic Analysis at each publication date for the data: GNP before the end of 1991, and GDP thereafter. For simplicity, we will often refer to this measure of output just as GDP. 
called "comprehensive" revisions that generally occur at a five-year frequency. The revision process incorporates additional source data and methodological changes such that the revised estimate of GDP growth in a given quarter may be quite different from the initial estimate. Indeed, over the past three decades, the average absolute revision to quarterly real GDP growth (expressed at an annual rate) is 1.7 percentage points. Our analysis of NIPA estimates is based on the Real Time Data Set for Macroeconomists compiled by the Federal Reserve Bank of Philadelphia. This data set contains successive snapshots of estimated GNP or GDP and its components beginning in the late 1960s, as well as financial-market information and other contemporaneous data.

The second section of the paper examines revisions to GDP growth for quarters close to business cycle peaks and troughs. We show that revisions significantly alter one's perception of the economy during key quarters of recent recessions. In addition, the average revision to real GDP growth is lower around cyclical peaks than during the full sample, and higher around cyclical troughs than during the full sample — which is consistent with the hypothesis described above. Yet, the relatively small number of business cycles in the sample puts a wide confidence range around these results. Therefore, the third section of the paper examines the link between revisions to GDP growth and accelerations and decelerations in real GDP throughout the sample. This more general analysis shows that estimates of real GDP growth tend to be revised down when economic activity is decelerating and revised up when it is accelerating. That is, provisional estimates of real GDP growth do not fully capture turning points in the economy.

The natural follow-up question is whether better use of contemporaneous data could improve the quality of provisional estimates, or whether the shortcomings of those estimates are intrinsic to the limited available source data. The fourth section of the paper studies the efficiency of the provisional estimates, building on earlier work by Mankiw and Shapiro (1986), Mork (1987), and others. We find that the advance estimates of real GDP growth during the past fifteen years have not been efficient forecasts of the current estimates, but instead could have been improved by incorporating information about financial markets, consumer sentiment, contemporaneous estimates of GDP growth in preceding quarters, and contemporaneous estimates of the acceleration in GDP. At the same time, this additional 
information reduces the standard error of the forecast by only about five percent.

This paper does not address the implications of data revisions for policymaking.

Nevertheless, two points deserve mention. First, some patterns of revision to estimated output growth are more relevant to countercyclical policy than others. Revisions to average output growth over a long period may be of limited relevance because they would generally imply corresponding revisions to potential output growth, leaving the output "gap" unchanged. In contrast, revisions to the quarterly dynamics of output — which are emphasized in our study - can have important implications for policymakers because such changes are unlikely to be associated with changes in potential output and therefore likely to result in a change in the output gap.

Second, our finding that provisional estimates of GDP growth do not fully capture economic turning points underscores the importance of policymakers assessing economic conditions using both NIPA estimates and other available information. Indeed, the transcripts of FOMC meetings in the late summer and fall of 1990 suggest that the FOMC recognized the possibility of future data revisions and gave substantial weight to anecdotal information about the slowing economy in setting policy. A growing literature evaluates monetary policy rules in the context of real-time data (for example, see Evans, 1998, and Orphanides, 2001).

\section{Revisions to National Income Data}

The NIPA data are constructed by the Bureau of Economic Analysis (BEA) at the Commerce Department. New and revised data are released electronically and on paper, and they are generally printed in the following month's Survey of Current Business. We utilize real-time estimates of key NIPA series from the Real Time Data Set for Macroeconomists (RTDSM), a relatively new data set created and maintained by the Federal Reserve Bank of Philadelphia. $^{2}$

\section{Data Releases and Revisions}

2. The RTDSM is publicly available at http://www.phil.frb.org/econ/forecast/reaindex.html. For background information, see Croushore and Stark (2000). 
The BEA's procedures for constructing the NIPA are described at length in Young and Tice (1985), Carson (1987), and Seskin and Parker (1998). We review this topic briefly here; Table 1 shows a summary of the timing of NIPA releases and revisions.

The first NIPA estimate for a quarter is the so-called "advance" release, which appears near the end of the first month following the quarter in question. ${ }^{3}$ The advance estimate of aggregate GDP is generally based on, among other inputs, three months of provisional data on retail sales, motor vehicle sales and inventories, shipments of business equipment, federal government outlays, and housing starts, as well as two months of data on construction, international trade, and inventory accumulation. The second NIPA estimate appears one month later and is known as the "preliminary" estimate. It incorporates revisions to the data just described and new source data, particularly for the third month of the quarter. The third estimate, labeled "final," appears another month later, just before the end of the following quarter. It includes further revisions to earlier data as well as new information about other parts of the accounts.

After the "final" release, NIPA estimates for a given quarter are not changed until the next "annual" or "comprehensive" revision. Annual revisions usually occur each summer, and they generally affect estimates for the preceding three years. They incorporate data that are more complete and more detailed than those used for earlier estimates, such as annual surveys of manufacturers, retailers, and service providers, as well as federal government budget data. Comprehensive revisions occur roughly every five years, and can change NIPA estimates back to the beginning of the data series (1929 for annual data and 1946 for quarterly data). These revisions use additional source data, update the seasonal factors, and incorporate major definitional and statistical improvements, such as the inclusion of depreciation of government fixed assets in government consumption (introduced in 1996) and the treatment of computer software as a final rather than intermediate product (introduced in 1999). Until the mid-1990s, comprehensive revisions were also the occasion for switching to a new "base" year for the fixed price weights used to aggregate real GNP or GDP, a subject that merits further

3. From 1965 through 1985, BEA also prepared a "flash" estimate about two weeks before the end of the quarter (and released this estimate to the public beginning in 1983). The RTDSM does not include these estimates, and we do not consider them further. 
discussion.

Before 1996, the BEA constructed inflation-adjusted (or "real") estimates of output in each year by calculating the value of output if all prices had remained at their level in some previous year. ${ }^{4}$ Goods with declining relative prices tend to have faster growth in quantities, so weighting these larger quantities by their earlier, higher prices tends to overstate aggregate real output." This so-called "substitution bias," common to all such fixed-weight measures, was greatly accentuated in the 1990s by the sharp decline in relative computer prices and the dramatic increase in computer purchases. In 1996, the BEA switched to a "chain-weighted" method for aggregating output and its components. With this approach, changes in quantities are weighted by an average of prices in adjacent periods; the period-by-period changes are "chained" together to form time series for which growth rates do not depend on the prices in a given base year.

Before the switch to chain aggregation, the change in the base year that accompanied most comprehensive revisions could result in large changes to the pattern of GNP or GDP growth. In particular, shifting to more recent prices as aggregation weights tended to reduce real growth rates, particularly for recently preceding years; this occurred because goods with declining relative prices, which generally experienced faster growth in quantities, received smaller weights. The 1996 conversion to chain-weighting replaced price weights from the most recent base year with price weights that were essentially contemporaneous. This shift went in the opposite direction of the traditional base-year updating, so it increased growth rates prior to the last base year. In sum, initial estimates for real growth prior to 1996 were based on prices from the preceding base year while current chain-weighted estimates are based on slightly later prices. Thus, the logic of substitution bias suggests (all else equal) that current estimates of real growth will be just slightly lower than initial estimates.

4. This discussion draws heavily on Landefeld and Parker (1995) and Whelan (2000).

5. Of course, demand shocks can lead prices and quantities to move in the same direction over short periods. Historically, however, appreciable movements in prices over extended periods have tended to reflect supply shifts. 


\section{Real Time Data Set for Macroeconomists}

The NIPA data in the Philadelphia Fed's real-time data set are the Survey of Current Business figures available as of the middle of each quarter. We transform quarterly real levels of output and its chief components into annualized growth rates, with the exception of inventory investment. Because the change in inventories can be either positive or negative, growth rates are not informative, and so we use the contribution of inventory accumulation to aggregate output growth. ${ }^{6}$ The data set includes the measure of aggregate output emphasized by the BEA at each publication date: GNP before the end of 1991, and GDP thereafter. We view this shift in focus as one of the many methodological changes in the measurement of aggregate output over time, and therefore our revisions series reflects this change. As noted earlier, we will generally refer to this series simply as "GDP" for ease of exposition. The data are continuous starting in the first quarter of 1966 for aggregate output and the last quarter of 1969 for most of the components; our sample generally begins somewhat later to allow for lags in the regressions. ${ }^{7}$

Table 2 summarizes the structure of the data. For the change in economic activity in each quarter, we have the BEA estimate as of the middle of the subsequent quarter and each quarter thereafter. Each row of the table corresponds to a quarter; the first figure shown in that row is the advance estimate of real GDP growth for that quarter, and the second figure is what we term the "following-quarter" estimate. In most cases, the following-quarter estimate will be the same as the BEA's "final" estimate, but it will be different for quarters when an annual or comprehensive revision occurred after the final release but before the RTDSM snapshot was taken in the middle of the next quarter. This small inconsistency in the series slightly changes the interpretation of some of our findings, but it has little impact on our major conclusions, which are based on the full revision from the advance estimate to the current estimate. Moving

6. To calculate this contribution, we divide the change in real inventory investment by real output in the previous period and then annualize. The resulting figure equals the contribution exactly for vintages based on fixed-base-year prices; it is a close approximation for vintages based on chain prices.

7. Advance estimates for the fourth quarter of 1995 are missing because of the federal government shutdown. 
further across the table, estimated real GDP growth changes as the data pass through annual and comprehensive revisions. For the "current" estimate, we take the value as of the second quarter of 2000 .

\section{Summary Statistics}

Table 3 presents summary statistics on estimates and revisions of real GNP and GDP growth. The top panel covers the advance, following-quarter, and current estimates; the middle panel reviews the revisions to growth rates among these sets of estimates; and the bottom panel reports on revisions to changes in growth rates between consecutive quarters (that is, to accelerations in output).

The table shows that revisions have had a large effect on both the average growth rate and the quarterly pattern of growth during the past three decades. Between 1968:Q1 and 2000:Q2, advance estimates of the percent change in real output averaged 2.6 percent (annual rate); current estimates average 3.3 percent, about two-thirds of a percentage point higher. The revisions between the advance and current estimates have been large relative to the variability of the advance estimates: the average absolute revision is 1.7 percentage points - nearly half as large as the 3.5 percentage point standard deviation of the advance estimates. The revisions have also been quite variable themselves, with a standard deviation exceeding 2 percentage points.

If the revisions to growth rates for consecutive quarters were highly positively correlated, then such revisions might have little effect on estimated accelerations and decelerations in output. However, the first-order autocorrelation coefficient of the advance to current revision is actually -0.11 . As a result, the revisions have significantly affected the changes in growth rates between quarters: the bottom panel of the table shows that the average absolute advance-to-current revision to the acceleration in output has been 2.5 percentage points.

The top panel of Figure 1 offers graphical perspective on the distribution of advance-tocurrent revisions to real GDP growth. The graph shows that a moderate number of revisions are small, with 22 percent of the sample less than $1 / 2$ percentage point in absolute value. However, many revisions are substantial: 44 percent of the revisions are larger than 1-1/2 percentage 
points in absolute value, and 20 percent of the revisions are larger than 2-1/2 percentage points in absolute value. The figure also shows that distribution of revisions is skewed somewhat to the right, consistent with the positive mean revision.

The middle and lower panels illustrate another interesting feature of the sample: the dispersion of revisions is smaller for more recent years than was in earlier years. For the earlier period, 56 percent of revisions were greater than 1-1/2 percentage points in absolute value, and 30 percent of revisions were greater than 2-1/2 percentage points in absolute value; the comparable numbers for the later periods are 32 percent and 11 percent. This reduction in the dispersion is not primarily a consequence of data from earlier years having gone through more revisions - even when "current" is defined as the value as of the end of 1983, 55 percent of absolute revisions in the earlier period are greater than 1-1/2 percentage points, and 22 percent are greater than 2-1/2 percentage points. Another possible explanation is that BEA has adjusted its methods over time, which might make its more recent initial estimates more accurate predictors of its ultimate estimates. Alternatively, the smaller revisions could be related to the fact that GDP growth (at least as measured) has become less volatile over time (McConnell and Perez-Quiros, 2000), which might make the initial estimates more reliable. We return to these possibilities later in the paper.

Figures 2 and 3 show the pattern of revisions to real GNP and GDP growth over time. The top panel of Figure 2 shows revisions between the advance and following-quarter estimates; the middle panel shows revisions between the following-quarter and current estimates; and the bottom panel shows revisions between the advance and current estimates. The shaded bars denote recessions according to the National Bureau of Economic Research (NBER) businesscycle chronology. The total revisions are large in many cases, and the lack of positive serial correlation is apparent.

In the top panel of Figure 3, the dashed line shows growth based on the advance estimates, and the solid line shows growth based on the current estimates. Although the basic history of expansions and contractions has not been altered by the revisions, a close look at the figure reveals many significant differences between the series. For example, the 1973-75 recession now appears much less deep than it did initially. The lower panel of Figure 3 shows 
revisions to eight-quarter changes in real output. ${ }^{8}$ By focusing on a measure that cumulates quarterly changes, we get a better sense of how the provisional data may have misled policymakers and others about the level of output and, in turn, the degree of resource utilization. $^{9}$ The graph shows long periods where the cumulative error was positive, implying that the provisional estimates substantially understated the level of real output.

Returning to Table 3, the middle panel shows that close to one-third of the overall impact of revisions has occurred between the advance and following-quarter estimates, and the remaining two-thirds has occurred in subsequent revisions. One might imagine that the annual and comprehensive revisions would affect primarily the trend change in GNP or GDP over some period, but in fact they have also generally affected the quarterly pattern of output changes. ${ }^{10}$ The top panel of Figure 4 shows revisions to real GDP growth associated with the 1996 comprehensive revision, when chain aggregation was introduced; the bottom panel shows revisions associated with the 1999 revision, when business spending on software was added to GDP. Despite the important methodological changes, which presumably generate fairly smooth revisions to GDP growth, the actual pattern of revisions shown in the charts in not smooth at all. Indeed, Seskin (1999, p. 35) summarized the results of the 1999 revision and noted that "revisions to the quarterly ... NIPA estimates reflect the revisions to the annual estimates, the incorporation of new and revised monthly and quarterly source data (including the updating of seasonal factors), and the introduction of changes in methodology (p. 35)."

Table 4 displays revisions to growth rates of the major components of GNP and GDP.

8. We thank Athanasios Orphanides for suggesting this graph.

9. This inference presumes that the implied level of potential output was not revised in lockstep with the level of actual output. As we noted in the introduction, revisions that have affected trends over long periods of time may well have fed directly through to estimates of potential output. However, the negative autocorrelation of revisions reported above implies that many of the revisions would not affect estimated potential output growth. Indeed, Orphanides and van Norden (1999) present evidence that real-time estimates of the output gap are severely biased around business cycle turning points because of the unreliability of end-of-sample estimates of the trend in output.

10. We calculate that the comprehensive revisions raised average output growth in our sample by 0.30 percentage point at an annual rate. 
Within consumption expenditures, the RTDSM allows us to examine durables, nondurables, and services separately, which is useful because of the wide variation across these categories in the amount of "hard" data underlying the initial estimates. Business fixed investment (BFI) includes both nonresidential structures and equipment and software (which is closely related to the traditional category of producers' durable equipment). ${ }^{11}$ Government spending refers to government consumption expenditures and gross investment; it does not include outlays for transfer programs.

Revisions to all categories contributed to the average upward revision to GDP (imports, which were revised down, affect output with a negative sign). The largest absolute revisions are for the growth rates of residential investment, imports, and exports. For each category of final demand, the final column shows the product of its average absolute revision and its average nominal share of output over the sample period to give a sense of its contribution to the variability of overall output revisions. For inventory investment, where the basic calculations are already based on the contribution to overall output, the comparable figure is just the average absolute revision. The figures show that the largest contributor to output revisions appears to be inventory investment, followed by consumption, government spending, and imports.

\section{Revisions Around Business Cycle Peaks and Troughs}

If provisional estimates do not entirely capture shifts in economic activity, then we would expect downward revisions around business cycle peaks and upward revisions around business cycle troughs. During the sample period of our data, the NBER has identified cyclical peaks in December 1969, November 1973, January 1980, July 1981, and July 1990, and cyclical troughs in November 1970, March 1975, July 1980, November 1982, and March 1991. In this section, we undertake a brief qualitative examination of key quarters during those recessions, and then present summary statistics for revisions around all of these business cycle peaks and troughs.

\section{Recessions in Our Sample}

In each of the plots in Figure 5, the left-most circle denotes the advance estimate of GNP

11. This category is the same as that termed "nonresidential fixed investment" by the BEA. 
or GDP growth for the quarter indicated, and each successive circle to the right denotes growth for that same quarter as estimated in following quarters. Comprehensive revisions are shown by vertical lines. ${ }^{12}$ For comparison purposes, the vertical scales of each plot span the same number of percentage points, although they are shifted up or down depending on the range of estimates for that quarter.

The top panel shows the beginning of the 1973-75 recession. In the middle of May 1974, the BEA estimated that real aggregate output increased at an annual rate of roughly 1-1/2 percent in the fourth quarter of 1973 and fell at an annual rate of close to 6 percent in the first quarter of 1974. By the middle of 2000, the BEA's estimates for those growth rates had evolved to 3-1/4 percent and -3 percent. Although the growth rates themselves are higher, the deceleration in economic activity was about the same as was perceived at the time. Thus, the episode yields no evidence that provisional estimates of decelerations tend to understate the actual decline in activity. Indeed, as noted in the discussion of Figure 3 above, the full peakto-trough deceleration for the 1973-75 episode is now estimated to be much smaller than implied by the advance estimates, with the change explained by upward revisions to the contributions of all of the major components of output.

The second panel of Figure 5 depicts the 1980 recession. In July 1981, when the NBER Business Cycle Dating Committee identified the trough of this recession, aggregate output appeared to have fallen sharply in the second quarter of the year and risen modestly in the third quarter. Although the episode did not seem to meet the popular definition of a recession as a decline in aggregate output lasting at least two quarters, the NBER (which does not rely on the popular definition) argued that the magnitude and breadth of the slowdown justified its designation as a recession. In retrospect, the downturn does appear to have extended across two quarters, with a somewhat smaller drop in output in the second quarter than initially believed, and a slight decline in the third quarter rather than a small increase.

12. Occasionally, historical estimates have changed slightly at times other than the comprehensive revision dates. For example, the BEA published an Errata several months after the 1991 comprehensive revision that included small changes to real GDP prior to the early 1970s. Another example occurred in the spring of 1997, when the BEA slightly modified its historical estimates to make them consistent with newly available wealth data. 
Overall, however, the revision to the basic dynamic of the recession looks to be fairly modest.

The third panel of Figure 5 displays the end of the 1981-82 recession. For the quarters preceding those shown, both provisional and current estimates of aggregate output growth involve substantial declines during 1981:Q4 and 1982:Q1, and a small increase in 1982:Q2. In the middle of February 1983, real output appeared to have edged up again in 1982:Q3 and then decreased at an annual rate of about 2-1/2 percent in 1982:Q4. Yet, current estimates imply a less choppy pattern to the recession, with output declining at an annual rate of close to 2 percent in the third quarter and then staying about flat in the fourth quarter. Despite this change, the revised estimates suggest no reason to question the date of November 1982 as the trough of the recession, and they contain only a hint that the acceleration in output coming out of the recession was understated.

Finally, we come to the beginning of the 1990-91 recession. As noted earlier, the growth rate of aggregate output in the third quarter was revised down substantially; the same is true for the fourth quarter, which now shows a considerably deeper decline than initially estimated. Of the four episodes highlighted in the chart, only this one supports the hypothesis that provisional estimates miss turning points.

In sum, Figure 5 shows that revised data sometimes reveal a different cyclical pattern than indicated by provisional estimates. Yet, we have not identified any gross revisions to the basic pattern of these recessions. Indeed, Grimm and Parker (1998) show that, with the exception of the 1990-91 episode, the advance estimates of output growth have correctly identified the preceding peaks for all recessions in our sample. ${ }^{13}$

\section{Systematic Patterns}

We now look for systematic patterns in the revisions to NIPA data around recessions. Table 5 shows average revisions to growth of aggregate GDP and its chief components, as well

13. According to Hall (2001), the NBER Business Cycle Dating Committee waits at least six months before considering whether a given date was a cyclical turning point, and it identifies changes in activity by considering a wide variety of indicators including industrial production, employment, real income, and trade. Thus, the NBER's business cycle chronology is somewhat insulated from mis-measurement in the BEA's provisional estimates. 
as standard errors indicating whether the averages are significantly different from zero. The first column corresponds to the full sample, repeating the information in the second column of Table 4. The next column shows average revisions during the two quarters up to and including business cycle peaks as identified by the NBER, and the third column shows the information for the two quarters following the peak. We include the period before the peak because GDP growth may decelerate as the peak approaches, and therefore this period may also be characterized by downward revisions if provisional data miss turning points. By the same logic, we show figures for the period just before a business cycle trough in the fourth column. The fifth column shows the two quarters after a trough.

Revisions to real GDP growth have been negative, on average, leading up to cyclical peaks, and positive immediately after the peaks. The averages are fairly small and not statistically distinguishable from zero. Revisions to GDP have been positive both before and after cyclical troughs. These averages are much larger-equal to or greater than 1 percentage point—but also statistically insignificant because of large standard errors.

A slightly different perspective comes from comparing the revisions around cyclical turning points to the average revision for the entire sample. Revisions to GDP growth have generally been below average around business cycle peaks and above average around business cycle troughs. The effects are roughly symmetric and are substantial, with the average of the two peak columns and the average of the two trough columns both implying deviations around one-half percentage point from the full-sample figure. While this pattern is consistent with the hypothesis that provisional estimates do not entirely capture shifts in economic activity, the standard errors are so large that the cyclical effects are not statistically significant even by this relative standard. ${ }^{14}$

Turning to the other rows of the table, we can examine the major components of GDP. As with the results for aggregate output, there are many coefficients of potential economic

14. The results are similar if one decomposes the overall revisions to GDP into the revisions between the advance and following-quarter estimates, and between the following-quarter and current estimates. Both of these types of revisions show smaller revisions than in the entire sample around business cycle peaks, and larger revisions than in the entire sample around business cycle troughs. 
significance, but few of statistical significance. The growth rate of consumer expenditures tends to be revised down around business cycle peaks, with some statistically significant results for both the durable goods and services subcategories. The revisions to all other domestic categories are too imprecisely estimated to draw any sort of conclusion. Revisions to export growth are large and positive around peaks and leading up to troughs; however, while some of the averages are significantly different from zero, they are not significantly different from the full-sample average, which is also large and positive. Revisions to import growth are large and negative around peaks, significantly different from zero and from the series' mean. Since imports typically decelerate going into a downturn, these numbers suggest that there is some tendency for imports to miss turning points. Note, however, that the overstatement of import growth in the provisional estimates leads to an understatement of output growth, so this effect could offset any tendency of other components of output to miss turning points. ${ }^{15}$

The final row of the table shows how the average absolute revision to GDP differs across the cycle. The average absolute revision for quarters close to the peak is about the same as the full sample figure, but the average absolute revision for quarters close to the trough is considerably larger. This suggests that provisional estimates tend to be less accurate as the economy comes out of a recession, although the standard errors are again so large that the difference is not statistically significant.

\section{Revisions to Accelerations and Decelerations Throughout the Sample}

The relatively small number of business cycles in the sample puts a wide confidence range around the averages shown in Table 5. Therefore, we switch to regression analysis to explore the properties of revisions when the sample is not limited to periods close to business cycle peaks.

15. This analysis may be distorted by the fact that real GDP rose in some NBER peak quarters and fell in others, and similarly for NBER trough quarters. To examine the importance of such dissimilarities, we repeated the Table 5 calculations using an alternative designation of peaks and troughs that assigned the peak to the quarter preceding the first quarter of negative growth and the trough to the quarter preceding the first quarter of positive growth. The results were quite similar qualitatively to the results shown for the NBER cyclical dates. For more on the timing of business cycle turning points, see Boldin (1994). 


\section{Methodology}

Define $X$ as the percent change (annual rate) in real output. We estimate regressions relating revisions to $X$ to accelerations in real output:

$$
X_{t}^{\text {current }}-X_{t}^{\text {provisional }}=\beta_{0}+\beta_{1} \text { Accel }_{t}^{\text {current }}+\epsilon_{t} \text {. }
$$

If output growth has been revised down in periods of negative acceleration (deceleration) and revised up in periods of positive acceleration, the estimated coefficient on the acceleration term will be positive.

An important feature of this equation is that the acceleration is derived from current data. This specification is appropriate if one is considering whether provisional estimates miss accelerations and decelerations, as these changes in the pace of activity are presumably best measured in the most recent data. It is worth emphasizing, however, that the exercise does not represent a test of the efficiency of provisional estimates, because we are using information that became available after the provisional estimates were constructed. We address this separate question in the next section.

We use as our explanatory variable different measures of the acceleration in output. To start, we use the simplest definition, the difference between the growth rate of real output in $t$ and in $t-1$ :

$$
\text { Accell }{ }_{t}^{\text {current }}=X_{t}^{\text {current }}-X_{t-1}^{\text {current }}
$$

We also use measures of accelerations that smooth through some of the choppiness in real output growth by taking the difference between the current period's growth rate and a weighted geometric average of growth in preceding quarters. In particular, we consider:

$$
\text { Accel2 } t^{\text {current }}=X_{t}^{\text {current }}-\left(X_{t-1}^{\text {current }}\right)^{\frac{1}{2}}\left(X_{t-2}^{\text {current }}\right)^{\frac{1}{2}}
$$

and

$$
\text { Accel3 }{ }_{t}^{\text {current }}=X_{t}^{\text {current }}-\left(X_{t-1}^{\text {current }}\right)^{\frac{4}{7}}\left(X_{t-2}^{\text {current }}\right)^{\frac{2}{7}}\left(X_{t-3}^{\text {current }}\right)^{\frac{1}{7}}
$$


These longer lags may correspond better to the notion that the BEA extrapolates "recent" experience. For this reason, we focus on the last definition of acceleration for much of our analysis and simply comment whenever the results differ for different lags (which they rarely do). Using even longer lags than shown here does not seem very useful, because that could extend right through a recession. Because of concerns expressed in earlier work (Mork, 1987, and Faust, Rogers, and Wright, 2000) about serial correlation in the error term, we correct the standard errors for heteroskedasticity and autocorrelation using the Newey and West (1987) procedure. ${ }^{16}$

\section{Results}

The first panel of Table 6 shows estimates based on the simplest measure of acceleration, Accell, and broken down by type of revision. In the first row, we see that the acceleration of GDP (as currently measured) has a positive and statistically significant effect on the revision between advance and following-quarter estimates; in other words, when GDP is accelerating, the advance estimate of GDP growth understates actual GDP growth as it will be perceived when additional data are available. The second row shows that the acceleration has a much larger positive effect on the revisions between the following-quarter and current estimates. As with the size of revisions in general, only a small share of the action occurs in the first couple of months after the advance estimate.

The third row considers the full revision, the difference between the current estimate and the advance estimate. A one percentage point acceleration in GDP growth (as measured by currently published data) is associated with a one-quarter percentage point upward revision after the advance estimate; correspondingly, a one percentage point deceleration in GDP would be associated with a one-quarter percentage point downward revision after the advance estimate. Implicitly, the remaining three-quarters of a percentage point of acceleration or deceleration is captured by the advance estimate. The R-squared statistic shows that such accelerations and decelerations explain just over one-quarter of the variation in revisions.

The second panel of the table shows how the results vary when the dependent variable

16. This correction makes little difference to the results. 
is the advance-to-current revision and the measure of acceleration is changed. The results are quite similar for the different accelerations; in each case a one percentage point acceleration seems to be associated with an upward revision to estimated GDP growth of about one-quarter percentage point. Decomposing these effects into the advance-to-following-quarter revisions and the following-quarter-to-current revisions also produces results (not shown) quite similar to those for our basic specification of acceleration. Throughout the rest of this section, we focus on the total revision between the advance and current estimates and on the acceleration relative to the weighted mean of the three previous quarters; we comment when these choices make a material difference in the results.

The next pair of rows splits the sample in the mid-1980s. As it turns out, the effect of accelerations on revisions is not markedly different across the two sample periods. If anything, the relationship is stronger in the later period during which the BEA's methods were most similar to those in use today.

We also consider the possibility that revisions are different in periods of positive and negative acceleration. To examine this question, the fourth panel in Table 6 shows regressions that include the product of the acceleration and a dummy variable that equals 1 if the acceleration is positive and 0 otherwise. The sum of the coefficients on the acceleration variable and the interaction term reflects the relationship between positive accelerations and revisions, whereas the first coefficient alone reflects the relationship between decelerations and revisions. As it turns out, this additional variable is insignificant, and its inclusion has fairly little effect on the other coefficient. The largest difference is for the recent sample period, for which the point estimate on the interaction term suggests that positive accelerations are associated with substantially larger revisions than are decelerations; however, this coefficient is not statistically significantly different from zero. ${ }^{17}$

The appendix contains results for a similar analysis of the components of GDP.

17. For the other measures of accelerations and types of revisions, the results (not shown) are similar to those for the baseline specification except when Accell is used with the advance-tocurrent revision. For this combination in the full sample, the coefficient on the acceleration and interaction terms are 0.14 and 0.24 respectively, and both are statistically significant at the 5 percent level. 


\section{Efficient Forecasts}

The preceding section addressed the question of whether provisional estimates of GDP growth fully capture turning points in the economy. In this section we turn to the follow-up question of whether better use of contemporaneous data could improve the quality of provisional estimates.

Theory

To answer this second question, we turn to the traditional framework for efficiency tests:

$$
X_{t}^{\text {current }}=\gamma_{0}+\gamma_{1} X_{t}^{\text {provisional }}+\gamma_{2} Z_{t}+\epsilon_{t}
$$

where $Z_{t}$ is restricted to data known at the time of the provisional release. ${ }^{18}$ If provisional forecasts are efficient, $\gamma_{1}$ should equal one and all other coefficients should be zero. To simplify the interpretation of the results, we rearrange equation (5) to yield:

$$
X_{t}^{\text {current }}-X_{t}^{\text {provisional }}=\gamma_{0}+\left(\gamma_{1}-1\right) X_{t}^{\text {provisional }}+\gamma_{2} Z_{t}+\epsilon_{t}
$$

In this case, the coefficients on all right-hand-side variables must equal zero for provisional estimates to be efficient forecasts.

Of course, a huge amount of information is available at the time that any given NIPA estimate is prepared, and therefore there are many potential candidates for $Z_{t}$. However, our

18. Equations (1) and (2) can be combined and rearranged to produce the following expression for the growth rate of real output as measured by current data:

$$
X_{t}^{\text {current }}=\frac{\beta_{0}}{1-\beta_{1}}+\frac{1}{1-\beta_{1}} X_{t}^{\text {provisional }}-\beta_{1} X_{t-1}^{\text {current }}+\epsilon_{t} .
$$

This equation may appear similar to a standard efficiency test, but it is actually fundamentally different because the independent variable $X_{t-1}{ }^{\text {current }}$ is not known in period $t$. Although equations (1) and (2) are the correct framework for considering whether true turning points are obscured by provisional estimates, they are not useful for addressing the separate question of whether those turning points could be better captured through more efficient use of data that are available on a contemporaneous basis. 
choice is limited from a practical perspective because contemporaneous estimates of variables that are later revised are generally quite difficult to obtain. Therefore, our analysis focuses mainly on variables from the RTDSM and variables that are never revised. Because using an exhaustive set of contemporaneous information is impossible, researchers cannot prove that provisional estimates are efficient forecasts of output; instead, they can either disprove that hypothesis or be unable to disprove it. Moreover, estimated deviations from efficiency should be evaluated in terms of their economic significance in addition to their statistical significance.

One variable that our earlier analysis suggests should be included in $Z_{t}$ is the provisional estimate of the acceleration in output. A link between provisional accelerations and subsequent revisions to output growth could arise if slowdowns and pickups in the wellmeasured components of output are ultimately recorded in other components that are initially extrapolated with a trend. Thus, a finding that provisional accelerations are positively correlated with revisions would demonstrate that an observed slowdown in output likely signals a more pronounced actual slowdown. We also include quarterly dummies, because the BEA often mentions the updating of seasonal factors in comprehensive revisions as an important source of change in the quarterly pattern of GDP growth (for example, Seskin and Sullivan, 1999). In addition, we test whether revisions are predicted by contemporaneous values of the unemployment rate, the index of consumer sentiment from the University of Michigan's Survey Research Center, the 3-month Treasury bill interest rate, the 10-year Treasury note interest rate, and the change in Standard and Poor's index of 500 stock prices, all of which are available when the advance estimates for a given quarter are prepared. ${ }^{19}$

Before presenting our results, we note some of the previous studies that consider the efficiency of provisional estimates of U.S. national income data, including Mankiw and Shapiro (1986), Mork (1987), Brodsky and Newbold (1994), Siklos (1996), Runkle (1998), and Faust, Rogers, and Wright (2000). ${ }^{20}$ Our analysis extends this earlier work in several

19. We take the contemporaneous estimate of the unemployment rate from the RTDSM; the other variables do not get revised, so we are able to use the history as currently reported.

20. Swanson and van Dijk (2001) evaluate the efficiency of preliminary estimates of industrial production, producer prices, and consumer prices. 
directions. First, we examine a longer sample period than most other studies and are able to include recent years when both economic relationships and the BEA's methodology most resemble those that prevail today. ${ }^{21}$ Second, we consider violations of efficiency using a larger set of variables such as consumer sentiment, the unemployment rate, and the provisional estimate of acceleration. As in the previous section, the use of this last variable allows us to specifically address the question of how data revisions change our perceptions of economic turning points. Third, we analyze both total GDP and its components.

\section{Results}

Table 7A presents efficiency tests for real GDP for the period 1968:Q1 through 2000:Q2. We have subtracted the mean from all explanatory variables so that the constant term equals the average revision over the estimation period. This revision is positive, as we reported in our previous tables, and statistically significant. Previous studies have also found that provisional estimates systematically understate later estimates (Mork, 1987; Brodsky and Newbold, 1994; Siklos, 1996; Faust, Rogers, and Wright, 2000). However, this deviation from forecast efficiency may be of limited relevance for countercyclical policy because revisions to growth rates across the sample often flow through to estimates of potential output growth, leaving the output gap — the variable of greatest interest to policymakers — unchanged.

As a benchmark, the first column shows the results when the only explanatory variable is a constant term; the standard error of the estimate is 2.13 percentage points. The second column adds quarterly dummies to the set of independent variables. The coefficients are statistically significant, which is unsurprising given that comprehensive NIPA revisions include the updating of seasonal factors. The inclusion of the quarterly dummies causes a modest reduction in the standard error to 2.06 percentage points. The third column adds the advance estimate of real GDP growth for each quarter, the fourth column adds the advance estimate of the acceleration in

21. For example, Mankiw and Shapiro (1986) considered the years 1975 through 1982; Mork (1987) analyzed data from 1974 to 1984; Brodsky and Newbold (1994) looked at the period 1978 to 1984, and Siklos (1996) examined data from 1975 through 1990. Runkle (1998) and Faust, Rogers and Wright (2000) use samples that are closer to ours, but they consider a more limited set of independent variables. 
real GDP, and the fifth column adds the remaining variables discussed above. As can be seen in the fifth column, the advance growth rate has a marginally significant coefficient of -0.20 , providing some evidence that estimated growth tends to be revised back toward the mean. The coefficient on provisional acceleration is positive, but not significantly different from zero, and none of the coefficients on the other variables is statistically distinguishable from zero. The standard error of the estimate for the full specification is 2.06 percentage points, the same as when only the quarterly dummies are included. These results suggest that no meaningful violations of efficiency are associated with any of the variables aside from the quarterly dummies.

Tables 7B and 7C show that the results are quite different when the sample is broken into the two sub-periods. For the early sample, shown in Table 7B, both the variables with significant coefficients and the magnitude of those coefficients are fairly similar to those for the full sample. The quarterly dummies are statistically significant, as is the advance growth rate of GDP, but little else appears to matter. The reduction in the standard error between the first and fifth columns is less than 5 percent, and it can be ascribed entirely to the inclusion of the quarterly dummies.

In the later sample, shown in Table 7C, the quarterly dummies are again significant, but the rest of the story changes materially. The coefficient on the advance growth rate is about negative one-half, implying that half of the deviation in the advance growth rate from its mean is reversed in subsequent revisions. The coefficient on acceleration is now large and significant, implying that an apparent acceleration of one percentage point in the provisional data suggests a subsequent upward revision of close to one-third percentage point. The financial variables now garner economically and statistically significant coefficients as well. The change in the S\&P 500 is significant and negative. A one percentage point increase in the three-month Treasury rate relative to its mean predicts a downward revision of more than onehalf percentage point in the growth estimate, while the same increase in the ten-year Treasury rate relative to its mean predicts an upward revision of about equal size. Thus, the average level of interest rates has no predictive power for revisions, but a steeper-than-usual yield curve presages an upward revision, and a flatter-than-usual yield curve signals a downward revision. Consumer sentiment has a positive coefficient, with a one-point increase (roughly 
one percent of the index's average value) associated with subsequent upward revisions to the growth rate of GDP of 0.1 percentage point. Still, despite the significance of the coefficients on these additional variables, the violation of efficiency remains of limited importance - the reduction in the standard error of the estimate when these variables are included in the specification is only 5 percent relative to the case where only a constant and quarterly dummies are included.

An additional variable that might improve the quality of provisional estimates is industrial production (IP). Hall (2001) mentions IP as one of the indicators monitored by the NBER Business Cycle Dating Committee. Although IP is not included in the RTDSM, we were able to obtain a nearly-continuous series of real-time estimates beginning in $1972 .{ }^{22}$ Using a slightly smaller sample, we reran our efficiency tests with the contemporaneous estimate of IP growth included in $Z_{t}$. For the earlier sample period (1972:Q2 through 1983:Q4), the coefficient on contemporaneous IP growth was statistically significant, with the standard error of the estimate about 5 percent lower than its counterpart from a regression that excluded IP. However, for the later sample period (1984:Q1 to 2000:Q2), the coefficient was not close to being significant and the other regression results were little changed.

The appendix presents efficiency tests for the primary components of GDP.

\section{Revisiting the Role of Comprehensive Revisions}

One potential problem with drawing lessons for the future from our analysis is that some of the past revisions reflect changes in BEA's methods and definitions that will not be repeated. Ideally, we would like to verify that our conclusions hold for a real-time output series based on current methods and definitions, but we lack sufficiently detailed real-time data to create such a series. $^{23}$ Nevertheless, we can show that some of the major changes to methods and definitions

22. We thank the Industrial Output section of the Federal Reserve Board for supplying us with these data. Because of the structure of the data set, we were unable to calculate real-time growth rates for several quarters following series breaks: 1976:Q2, 1985:Q2, and 1990:Q1.

23. For some changes, the necessary data never existed. For example, we cannot include business spending on software on a real-time basis before 1999 because the BEA did not construct these data until they were added to GDP. 
do not appear to be driving factors behind the pattern of revisions that we have discussed.

First, our results are robust to excluding business spending on software — added in the 1999 comprehensive revision - from the "current" estimate of real GDP. To demonstrate this point, we used chain aggregation to remove software from the current estimate and recalculated the advance-to-current revision. This new revisions series runs only through the second quarter of 1999, as real-time estimates after the inclusion of software are not consistent with the altered current GDP series. We re-estimated equations (1) and (6) over this slightly shorter time period using both the modified revisions series and the baseline revisions series, and we found the results to be very similar.

Second, we did a similar exercise that removed both business software and government consumption of fixed capital — added in the 1996 comprehensive revision — from our current estimate of real GDP. The available sample for this estimation is considerably smaller than our base sample, because the BEA has not released its estimate of government consumption of fixed capital before 1987. Still, the regression results for the resulting measure of revisions are qualitatively similar to those for the baseline measure of revisions.

Third, the conversion to chain aggregation in the 1996 comprehensive revision eliminated an important source of revisions to the data in earlier comprehensive revisions. As we discussed in Section 1, changes in the base year often led to substantial revisions when real output was calculated using fixed weights. However, such revisions were largely undone when the introduction of chain aggregation shifted the aggregation weights to essentially contemporaneous prices. Because most early estimates of output were aggregated using prices from a fairly recent base year, the weights used under chain aggregation are likely generally much closer to the original weights than those used in previous comprehensive revisions. As a result, the successive revisions to growth rates based on shifting base years and switching to chain aggregation net out close to zero, and thus have relatively little impact on our measure of the revisions to real output between the advance and current estimates.

\section{Conclusions and Caveats}

This paper has uncovered some notable features of provisional estimates of real GNP and GDP growth. First, provisional estimates generally do not fully capture accelerations and 
decelerations in output, implying some tendency to miss economic turning points. Second, "advance" estimates of real output growth during the past fifteen years have not been efficient forecasts of current estimates, but instead could have been improved by incorporating information about financial markets, consumer sentiment, provisional estimates of recent output growth, and the acceleration in such growth. Nonetheless, the improvement in forecast quality from including these additional contemporaneous data appears to be small, with the standard error of the forecast reduced by only about five percent.

The primary caveat to these results concerns the evolution over time of data construction methods and definitions. As discussed in Section 5, some comprehensive revisions introduced important changes that had one-time effects on the relationship of current estimates to earlier provisional estimates. Although this could imply that patterns of past revisions have limited relevance for today's provisional estimates, we presented evidence that some of the key changes had little effect on the patterns that we have highlighted. 


\section{References}

Boldin, Michael D. 1994. "Dating Turning Points in the Business Cycle." Journal of Business 67 no. 1 (January): 97-131.

Brodsky, Noel and Paul Newbold. 1994. "Late Forecasts and Early Revisions of United States GNP.” International Journal of Forecasting 10 no. 3 (November): 455-460.

Carson, Carol S. 1987. "GNP: An Overview of Source Data and Estimating Methods." Survey of Current Business 67 no. 7 (July): 103-26.

Croushore, Dean and Tom Stark. 2000. “A Real-Time Data Set for Macroeconomists: Does Data Vintage Matter for Forecasting?” Federal Reserve Bank of Philadelphia Working Paper no. 00-6 (June).

Evans, Charles L. 1998. "Real-Time Taylor Rules and the Federal Funds Futures Market." Economic Perspectives (Third Quarter): 44-55.

Faust, Jon, John H. Rogers, and Jonathan H. Wright. 2000. "News and Noise in G-7 GDP Announcements." Federal Reserve Board International Finance Discussion Paper no. 2000-690 (December).

Grimm, Bruce T. and Robert P. Parker. 1998. "Reliability of the Quarterly and Annual Estimates of GDP and Gross Domestic Income." Survey of Current Business 78 no. 12 (December): 12-21.

Hall, Robert E. 2001. The NBER's Recession Dating Procedure in the Light of Current Developments [online]. National Bureau of Economic Research (June). Available from: http://www.nber.org/cycles/recessions.html [Accessed June 13, 2001].

Landefeld, J. Steven and Robert P. Parker. 1995. "Preview of the Comprehensive Revision of the National Income and Product Accounts: BEA's New Featured Measures of Output and Prices." Survey of Current Business 75 no. 7 (July): 31-38.

Mankiw, N. Gregory and Matthew D. Shapiro. 1986. "News or Noise: An Analysis of GNP Revisions." Survey of Current Business 66, no. 5 (May): 20-25.

McConnell, Margaret M. and Gabriel Perez-Quiros. 2000. "Output Fluctuations in the United States: What Has Changed since the Early 1980's?" American Economic Review 90, no. 5 (December): 1464-76. 
Mork, Knut Anton. 1987. “Ain't Behavin': Forecast Errors and Measurement Errors in Early GNP Estimates.” Journal of Business and Economic Statistics 5, no. 2 (April): 165-75.

Newey, Whitney K. and Kenneth D. West. 1987. "A Simple, Positive Semi-definite, Heteroskedasticity and Autocorrelation Consistent Covariance Matrix." Econometrica 55 no. 3 (May): 703-708.

Orphanides, Athanasios. 2001. "Monetary Rules Based on Real-Time Data." American Economic Review 91 no. 4 (September): 964-985.

Orphanides, Athanasios and Simon van Norden. 1999. "The Reliability of Output Gap Estimates in Real Time.” Federal Reserve Board Finance and Economics Discussion Series working paper no. 1999-38 (July).

Runkle, David E. 1998. "Revisionist History: How Data Revisions Distort Economic Policy Research." Federal Reserve Bank of Minneapolis Quarterly Review 22 no. 4 (Fall): 3-12.

Seskin, Eugene P. and Robert P. Parker. 1998. "A Guide to the NIPA's." Survey of Current Business 78 no. 3 (March): 26-68.

Seskin, Eugene P. and David F. Sullivan. 1999. "Annual Revision of the National Income and Product Accounts." Survey of Current Business 79 no. 8 (August): 6-33.

Seskin, Eugene P. 1999. "Improved Estimates of the National Income and Product Accounts for 1959-98: Results of the Comprehensive Revision." Survey of Current Business 79 no. 12 (December): 15-43.

Siklos, Pierre. 1996. "An Empirical Exploration of Revisions in U.S. National Income Aggregates." Applied Financial Economics 6 no. 1 (February): 69-70.

Swanson, Norman R. and Dick van Dijk. 2001. "An Evaluation of Preliminary Data Announcement Rationality and Business Cycle Asymmetry.” Mimeo (July).

Whelan, Karl. 2000. "A Guide to the Use of Chain-Aggregated NIPA Data." Federal Reserve Board Finance and Economics Discussion Series working paper no. 2000-35 (June).

Young, Allan H., and Helen Stone Tice. 1985. "An Introduction to National Economic Accounting," Survey of Current Business 65 no. 3 (March): 59-76. 


\section{Appendix \\ Regression Results for the Components of GNP and GDP}

\section{Revisions to Accelerations and Decelerations}

Table A1 presents results from estimating equation (1) for components of GDP:

$$
X_{t}^{\text {current }}-X_{t}^{\text {provisional }}=\beta_{0}+\beta_{1} \text { Accel }_{t}^{\text {current }}+\epsilon_{t},
$$

where $X_{t}$ corresponds to the percent change in one of the components of GDP and Accel $_{t}$ is also based on that component. In all cases, the dependent variable is the advance-to-current revision, and the independent variables are based on the acceleration relative to the weighted average of the three preceding quarters. We show results for the specification that allows the effect of acceleration to differ depending on its sign because the difference is sometimes meaningful.

For consumer expenditures, decelerations lead to future upward revisions (because a negative value for acceleration is multiplied by a negative coefficient), and accelerations lead to positive revisions of similar magnitude (because the sum of the acceleration and interaction coefficients is roughly the opposite of the acceleration coefficient alone). In this case, the provisional data seem to miss part of accelerations (requiring a later upward revision) but overstate decelerations (requiring a later upward revision), effects that are especially strong in the second half of the sample. Decomposing consumer spending reveals very different patterns across its components. For durables, decelerations have no correlation with subsequent revisions, and accelerations are correlated with subsequent positive revisions in the second half of the sample only. For nondurables, neither accelerations nor decelerations have any significant relationship with revisions. For services, both accelerations and decelerations lead to significant revisions, with the estimated coefficients implying that the provisional estimates capture less than half of the acceleration or deceleration in this category.

For the components of investment (business fixed, inventory, and residential), we find no systematic relationships between revisions and accelerations. But accelerations and decelerations of both government expenditures and exports are positively associated with revisions, particularly in the earlier sample period. Finally, for imports in the later sample period, negative accelerations are associated with large downward revisions, and positive 
accelerations are associated with small downward revisions.

\section{Efficiency Tests}

Table A2 presents efficiency tests for the components of real GDP. We estimate equation (6):

$$
X_{t}^{\text {current }}-X_{t}^{\text {provisional }}=\gamma_{0}+\left(\gamma_{1}-1\right) X_{t}^{\text {provisional }}+\gamma_{2} Z_{t}+\epsilon_{t},
$$

where $X_{t}$ again represents the percent change in a component of real GDP. For $Z_{t}$, we use the full set of variables corresponding to the last columns of Tables 7A through 7C. The first column of each panel gives results for the entire sample, and the second and third columns show results for the two sub-periods. Our goal is to understand which components drive the relationships observed for total GDP. However, the patterns often vary across time periods, making a concise presentation of the results difficult.

For consumer expenditures and its components, the estimated coefficients are similar to those for overall GDP. The coefficients on the advance growth rate are well below zero, especially for nondurables and services. The financial variables have coefficients that are seldom economically or statistically significant in the early sample, but often important in the late sample. Perhaps not surprisingly, consumer sentiment has a distinct positive effect in many of the specifications. For durables spending, these additional variables provide little explanatory power for revisions, as can be seen by comparing the standard error of the estimate under the full specification and under a "benchmark" specification where the only explanatory variable is a constant (as in the first column of Tables 8A through 8C). By contrast, the variables generate a moderate improvement in the predictability of revisions to services spending and a sizable improvement in the predictability of revisions to nondurables spending. Altogether, the inclusion of additional contemporaneous data reduces the standard error of the estimate for consumer spending by about 20 percent.

Turning to business investment, the patterns are rather different. For fixed investment, the advance estimate of the growth rate enters insignificantly in all of the sample periods, while the advance acceleration has a significant negative coefficient in both the full and early samples. The quarterly dummies are statistically significant, but the financial variables, 
consumer sentiment, and the unemployment rate appear to play little role. All of these variables together reduce the standard error of the estimate by only about 10 percent. For the contribution of inventory investment to GDP growth, the coefficient on the advance estimates are close to negative one-half and highly statistically significant, consistent with this category being initially quite poorly measured. The other variables are generally insignificant, and the standard error of the estimate is reduced by roughly 15 percent.

For residential investment, we find that the advance growth rate matters significantly only in the early sample, while the advance acceleration has a significant negative coefficient in the full and late samples. Most of the other variables are again unimportant, and the reduction in the standard error of the estimate associated with including the additional variables is again roughly 10 percent.

The estimates for government spending suggest a strong tendency for provisional estimates of growth to revise back toward the mean, with the coefficients on the advance growth rates ranging from -0.66 to -0.79 and highly statistically significant. Few other variables enter significantly, but the overall improvement in the standard error of the estimate is large, especially for the late sample.

Finally, we turn to the foreign sector. Because the coefficients in both the exports and imports regressions show few systematic patterns across the two sub-periods, our discussion focuses on the later period. For exports, the advance growth rate and advance acceleration have a negative and marginally significant effect on subsequent revisions. The other variables are generally unimportant, and the reduction in the standard error of the estimate relative to the benchmark case is just over 10 percent. The results for imports are qualitatively similar, but the negative coefficient on the advance growth rate is much larger and more significant, generating a greater than 40 percent reduction in the standard error of the estimate. 
Table 1

Timing of GDP Releases and Revisions

\begin{tabular}{|c|c|c|}
\hline Name & Timing & Selected Sources \\
\hline Advance Release & $\begin{array}{l}\text { End of first month in } \\
\text { subsequent quarter. }\end{array}$ & $\begin{array}{l}\text { Three months of provisional data on consumer } \\
\text { spending on goods as well as shipments of } \\
\text { business equipment; two months of provisional } \\
\text { data on construction, international trade, and } \\
\text { inventories. }\end{array}$ \\
\hline $\begin{array}{l}\text { Preliminary } \\
\text { Release }\end{array}$ & $\begin{array}{l}\text { End of second month } \\
\text { in subsequent quarter. }\end{array}$ & $\begin{array}{l}\text { Revisions to provisional data used for advance } \\
\text { estimate; new source data for third month of } \\
\text { quarter. }\end{array}$ \\
\hline Final Release & $\begin{array}{l}\text { End of third month in } \\
\text { subsequent quarter. }\end{array}$ & $\begin{array}{l}\text { Further revisions to source data used for } \\
\text { advance and preliminary estimates. }\end{array}$ \\
\hline Annual Revision & $\begin{array}{l}\text { Usually summer of } \\
\text { subsequent year and } \\
\text { several years } \\
\text { thereafter. }\end{array}$ & $\begin{array}{l}\text { Annual surveys of manufacturers, wholesale } \\
\text { and retail trade merchants, services, } \\
\text { construction put-in-place, and state and local } \\
\text { governments; federal government budget } \\
\text { data; international transactions accounts. }\end{array}$ \\
\hline $\begin{array}{l}\text { Comprehensive } \\
\text { Revision }\end{array}$ & $\begin{array}{l}\text { Usually about every } \\
\text { five years. }\end{array}$ & $\begin{array}{l}\text { Data from sources used for annual revisions } \\
\text { as well as sources that become available less } \\
\text { frequently such as economic censuses. } \\
\text { Methods and definitions may also change. } \\
\text { 1976: Changed base year from } 1958 \text { to } 1972 . \\
\text { 1985: Changed base year from } 1972 \text { to } 1982 \text {; } \\
\text { introduced quality-adjusted price } \\
\text { indexes for computers. } \\
\text { 1991: Changed base year from } 1982 \text { to } 1987 \text {; } \\
\text { switched emphasis from GNP to GDP. } \\
\text { 1996: Changed to chain-weighting; } \\
\text { included depreciation of government } \\
\text { fixed assets as government } \\
\text { consumption. }\end{array}$ \\
\hline
\end{tabular}

Note. From 1965 through 1985, BEA also prepared a "flash" estimate about two weeks before the end of the quarter (and released this estimate to the public beginning in 1983). We do not consider these estimates in our analysis. 
Table 2

Successive Estimates of the Growth Rate of GNP or GDP, as Drawn from the Real Time Data Set for Macroeconomists

\begin{tabular}{|c|c|c|c|c|c|c|c|}
\hline \multirow[t]{2}{*}{ Quarter } & \multicolumn{7}{|c|}{ Vintage of Estimate } \\
\hline & 1970:Q3 & 1970:Q4 & 1971:Q1 & 1971:Q2 & $1971: 3$ & $\ldots$ & current \\
\hline 1970:Q2 & 0.28 & 0.61 & 0.61 & 0.61 & 0.72 & & 0.83 \\
\hline 1970:Q3 & & 1.44 & 1.39 & 1.39 & 1.23 & & 3.55 \\
\hline 1970:Q4 & & & -3.31 & -3.85 & -4.03 & & -4.23 \\
\hline 1971:Q1 & & & & 6.42 & 7.94 & & 11.65 \\
\hline$\cdots$ & & & & & & & \\
\hline
\end{tabular}

Note. The "current" value is the value as of 2000:Q2. 
Table 3

Summary Statistics on Estimates and Revisions of Real GNP or GDP Growth

\begin{tabular}{l|c|c|c}
\multicolumn{6}{l|}{ Growth rates } & advance estimate & $\begin{array}{c}\text { following-quarter } \\
\text { estimate }\end{array}$ & current estimate \\
\hline mean & 2.64 & 2.81 & 3.27 \\
standard deviation & 3.46 & 3.71 & 3.66 \\
\hline
\end{tabular}

Revisions to growth rates

\begin{tabular}{l|c|c|c}
\hline & $\begin{array}{c}\text { advance to } \\
\text { following-quarter }\end{array}$ & $\begin{array}{c}\text { following-quarter to } \\
\text { current }\end{array}$ & advance to current \\
\hline mean & 0.19 & 0.46 & 0.63 \\
mean absolute value & 0.67 & 1.58 & 1.66 \\
standard deviation & 0.81 & 2.06 & 2.13 \\
\hline
\end{tabular}

Revisions to changes in growth rates (i.e., revisions to accelerations)

\begin{tabular}{l|c|c|c}
\hline & $\begin{array}{c}\text { advance to } \\
\text { following-quarter }\end{array}$ & $\begin{array}{c}\text { following-quarter to } \\
\text { current }\end{array}$ & advance to current \\
\hline mean & 0.22 & -0.01 & 0.18 \\
mean absolute value & 0.73 & 2.35 & 2.48 \\
standard deviation & 0.95 & 2.98 & 3.10 \\
\hline
\end{tabular}

Notes. Sample period is 1968:Q1 to 2000:Q2. Comprehensive revisions have increased estimated mean real aggregate output growth by 0.30 percentage point, close to half of the total mean revision of 0.63 percentage point. Comprehensive revisions in 1976, 1980, 1985, and 1991 reduced estimated growth on average. The 1996 revision raised average growth by 0.17 percentage point, and the 1999 revision raised it by 0.25 percentage point. 
Table 4

Revisions to Growth Rates of Components of GNP or GDP

\begin{tabular}{|c|c|c|c|c|c|}
\hline output component & $\begin{array}{l}\text { average } \\
\text { value in } \\
\text { current } \\
\text { data }\end{array}$ & $\begin{array}{l}\text { average } \\
\text { revision }\end{array}$ & $\begin{array}{l}\text { average } \\
\text { absolute } \\
\text { revision }\end{array}$ & $\begin{array}{l}\text { average } \\
\text { nominal } \\
\text { share of } \\
\text { output }\end{array}$ & $\begin{array}{l}\text { avg. abs. } \\
\text { revision to } \\
\text { growth } \\
\text { x nominal } \\
\text { share }\end{array}$ \\
\hline Output (GNP/GDP) & 3.27 & $\begin{array}{l}.63^{* *} \\
(.19)\end{array}$ & $\begin{array}{l}1.66^{* *} \\
(.13)\end{array}$ & 1.00 & $\dagger$ \\
\hline $\begin{array}{l}\text { Consumption } \\
\text { expenditures }\end{array}$ & 3.40 & $\begin{array}{l}.28^{*} \\
(.15)\end{array}$ & $\begin{array}{l}1.27^{* *} \\
(.09)\end{array}$ & .65 & .82 \\
\hline Durable goods & 6.08 & $\begin{array}{l}.43 \\
(.46)\end{array}$ & $\begin{array}{l}4.03^{* *} \\
(.29)\end{array}$ & .08 & .33 \\
\hline Nondurable goods & 2.68 & $\begin{array}{l}.54^{* *} \\
(.22)\end{array}$ & $\begin{array}{l}1.92^{* *} \\
(.14)\end{array}$ & .23 & .44 \\
\hline Services & 3.50 & $\begin{array}{l}.14 \\
(.15)\end{array}$ & $\begin{array}{l}1.32^{* *} \\
(.09)\end{array}$ & .34 & .44 \\
\hline $\begin{array}{l}\text { Business fixed } \\
\text { investment }\end{array}$ & 5.75 & $\begin{array}{l}1.13^{* *} \\
(.54)\end{array}$ & $\begin{array}{l}4.50^{* *} \\
(.37)\end{array}$ & .11 & .52 \\
\hline Inventory investment & .03 & $\begin{array}{l}.03 \\
(.17)\end{array}$ & $\begin{array}{l}1.30^{* *} \\
(.12)\end{array}$ & $\dagger$ & $\dagger$ \\
\hline Residential investment & 4.48 & $\begin{array}{l}.39 \\
(.91)\end{array}$ & $\begin{array}{l}7.38^{* *} \\
(.62)\end{array}$ & .04 & .32 \\
\hline Government & 1.73 & $\begin{array}{l}.04 \\
(.42)\end{array}$ & $\begin{array}{l}3.29^{* *} \\
(.29)\end{array}$ & .20 & .67 \\
\hline Exports & 7.48 & $\begin{array}{l}3.27^{* *} \\
(.67)\end{array}$ & $\begin{array}{l}6.11^{* *} \\
(.47)\end{array}$ & .09 & .53 \\
\hline Imports & 7.42 & $\begin{array}{r}-0.20 \\
(.86)\end{array}$ & $\begin{array}{l}6.52^{* *} \\
(.62)\end{array}$ & .10 & .64 \\
\hline
\end{tabular}

Notes. Statistics for output calculated for 1968:Q1 to 2000:Q2; statistics for components calculated for 1969:Q4 to 200:Q2. Standard errors are in parentheses; ${ }^{*}$ and ${ }^{* *}$ denote coefficients that statistically significantly different from zero at the $10 \%$ and $5 \%$ levels. Revisions pertain to annualized growth rates for all components except inventory investment, for which they represent contributions to output growth. † indicates the calculation does not apply. 
Table 5

Average Revisions Around Business Cycle Peaks and Troughs

\begin{tabular}{|c|c|c|c|c|c|}
\hline output component & all quarters & $\begin{array}{l}2 \text { quarters } \\
\text { up to and } \\
\text { incl. peaks }\end{array}$ & $\begin{array}{c}2 \text { quarters } \\
\text { after } \\
\text { peaks }\end{array}$ & $\begin{array}{l}2 \text { quarters } \\
\text { up to and } \\
\text { incl. troughs }\end{array}$ & $\begin{array}{c}2 \text { quarters } \\
\text { after } \\
\text { troughs }\end{array}$ \\
\hline Output (GNP/GDP) & $\begin{array}{l}.63^{* *} \\
(.19)\end{array}$ & $\begin{array}{l}-.27 \\
(.98)\end{array}$ & $\begin{array}{l}.40 \\
(.53)\end{array}$ & $\begin{array}{l}1.29 \\
(.98)\end{array}$ & $\begin{array}{l}1.05 \\
(.86)\end{array}$ \\
\hline $\begin{array}{l}\text { Consumption } \\
\text { expenditures }\end{array}$ & $\begin{array}{l}.28^{*} \\
(.15)\end{array}$ & $\begin{array}{l}-.38 \\
(.66)\end{array}$ & $\begin{array}{l}-.64^{* *} \\
(.20)\end{array}$ & $\begin{array}{l}1.02 \\
(.59)\end{array}$ & $\begin{array}{l}-.80 \\
(.47)\end{array}$ \\
\hline Durable goods & $\begin{array}{c}.43 \\
(.46)\end{array}$ & $\begin{array}{c}-.73 \\
(2.04)\end{array}$ & $\begin{array}{c}-2.42^{* *} \\
(.90)\end{array}$ & $\begin{array}{c}1.43 \\
(1.29)\end{array}$ & $\begin{array}{l}-1.82 \\
(1.29)\end{array}$ \\
\hline Nondurable goods & $\begin{array}{l}.54^{* *} \\
(.22)\end{array}$ & $\begin{array}{l}-.37 \\
(.85)\end{array}$ & $\begin{array}{l}-.29 \\
(.53)\end{array}$ & $\begin{array}{l}.19 \\
(.49)\end{array}$ & $\begin{array}{l}-.49 \\
(.78)\end{array}$ \\
\hline Services & $\begin{array}{l}.14 \\
(.15)\end{array}$ & $\begin{array}{r}-1.21^{*} \\
(.62)\end{array}$ & $\begin{array}{l}-.71 \\
(.48)\end{array}$ & $\begin{array}{l}.49 \\
(.68)\end{array}$ & $\begin{array}{l}.27 \\
(.58)\end{array}$ \\
\hline $\begin{array}{l}\text { Business fixed } \\
\text { investment }\end{array}$ & $\begin{array}{l}1.13^{* *} \\
(.54)\end{array}$ & $\begin{array}{c}2.44 \\
(2.30)\end{array}$ & $\begin{array}{c}1.64 \\
(2.53)\end{array}$ & $\begin{array}{c}2.01 \\
(1.19)\end{array}$ & $\begin{array}{l}-1.25 \\
(2.15)\end{array}$ \\
\hline $\begin{array}{l}\text { Inventory } \\
\text { investment }\end{array}$ & $\begin{array}{l}.03 \\
(.17)\end{array}$ & $\begin{array}{l}-.94 \\
(.82)\end{array}$ & $\begin{array}{l}.31 \\
(.33)\end{array}$ & $\begin{array}{l}.17 \\
(.68)\end{array}$ & $\begin{array}{l}.64 \\
(.98)\end{array}$ \\
\hline $\begin{array}{l}\text { Residential } \\
\text { investment }\end{array}$ & $\begin{array}{l}.39 \\
(.91)\end{array}$ & $\begin{array}{l}-2.96 \\
(4.47)\end{array}$ & $\begin{array}{l}-1.29 \\
(3.20)\end{array}$ & $\begin{array}{c}7.01 \\
(4.01)\end{array}$ & $\begin{array}{l}-3.40 \\
(3.68)\end{array}$ \\
\hline Government & $\begin{array}{l}.04 \\
(.42)\end{array}$ & $\begin{array}{c}-.72 \\
(1.36)\end{array}$ & $\begin{array}{c}.64 \\
(1.06)\end{array}$ & $\begin{array}{l}-.59 \\
(.84)\end{array}$ & $\begin{array}{c}.85 \\
(1.53)\end{array}$ \\
\hline Exports & $\begin{array}{l}3.27^{* *} \\
(.67)\end{array}$ & $\begin{array}{l}4.77 \\
(2.61)\end{array}$ & $\begin{array}{r}5.37^{*} \\
(2.62)\end{array}$ & $\begin{array}{r}6.32^{*} \\
(2.94)\end{array}$ & $\begin{array}{c}1.26 \\
(3.48)\end{array}$ \\
\hline Imports & $\begin{array}{l}-.20 \\
(.86)\end{array}$ & $\begin{array}{l}-6.35^{* *} \\
(2.49)\end{array}$ & $\begin{array}{l}-4.03^{*} \\
(2.01)\end{array}$ & $\begin{array}{c}.33 \\
(2.89)\end{array}$ & $\begin{array}{l}-1.14 \\
(2.52)\end{array}$ \\
\hline $\begin{array}{l}\text { Memo: avg absolute } \\
\text { revision to output }\end{array}$ & $\begin{array}{l}1.66 \\
(.14)\end{array}$ & $\begin{array}{l}1.87 \\
(.67)\end{array}$ & $\begin{array}{l}1.46 \\
(.26)\end{array}$ & $\begin{array}{l}2.54 \\
(.65)\end{array}$ & $\begin{array}{l}2.43 \\
(.45)\end{array}$ \\
\hline
\end{tabular}

Notes. Statistics for output calculated for 1968:Q1 to 2000:Q2; statistics for components calculated for 1969:Q4 to 2000:Q2. Standard errors are in parentheses; ${ }^{*}$ and ${ }^{* *}$ denote coefficients that statistically significantly different from zero at the $10 \%$ and $5 \%$ levels. Revisions pertain to annualized growth rates for all components except inventory investment, for which they represent contributions to output growth. As identified by the NBER, business cycle peaks are 1969:Q4, 1973:Q4, 1980:Q1, 1981:Q3, and 1990:Q3; business cycle troughs are 1970:Q4, 1975:Q1, 1980:Q3, 1982:Q4, and 1991:Q1. 
Table 6

Effect of Accelerations on Revisions to GNP or GDP Growth

\begin{tabular}{l|c|c|c|c|c}
\hline & constant & accel. & $\begin{array}{c}\text { accel. } \mathrm{x} \\
\text { (accel. > 0) }\end{array}$ & $\mathrm{R}^{2}$ & $\hat{\rho}$ \\
\hline \multicolumn{5}{l}{ Using different types of revision as dep. variable (indep. variable $=$ Accel1): } \\
\hline advance to & $.19^{* *}$ & $.06^{* *}$ & $\ldots$ & .12 & -.11 \\
following-quarter & $(.06)$ & $(.01)$ & & .17 & .01 \\
following-quarter to & $.45^{* *}$ & $.20^{* *}$ & $\ldots$ & .28 & .06 \\
current & $(.16)$ & $(.04)$ & & \\
advance to current & $.63^{* *}$ & $.26^{* *}$ & $\ldots$ & & \\
\hline
\end{tabular}

Using different accelerations as indep. variable (dep. variable = advance to current revision):

\begin{tabular}{l|ccccc}
\hline Accel2 & $.62^{* *}$ & $.28^{* *}$ & $\ldots$ & .27 & .03 \\
& $(.15)$ & $(.06)$ & & & \\
Accel3 & $.62^{* *}$ & $.30^{* * *}$ & $\ldots$ & .29 & .08 \\
& $(.15)$ & $(.05)$ & & & \\
\hline
\end{tabular}

Splitting the sample (dep. variable = advance to current revision; indep. variable = Accel3):

\begin{tabular}{l|ccccc}
\hline 1968:Q1 to $1983: Q 4$ & $.67^{* *}$ & $.28^{* *}$ & $\ldots$ & .28 & .11 \\
& $(.28)$ & $(.06)$ & & & \\
1984:Q1 to 2000:Q2 & $.58^{* *}$ & $.39^{* *}$ & $\ldots$ & .39 & -.05 \\
& $(.13)$ & $(.05)$ & & & \\
\hline
\end{tabular}

Comparing accelerations with decelerations (dep. variable = advance to current revision; indep. variable $=$ Accel3):

\begin{tabular}{l|ccccc}
\hline 1968:Q1 to 2000:Q2 & $.50^{* *}$ & $.25^{* *}$ & .08 & .30 & .08 \\
& $(.23)$ & $(.08)$ & $(.13)$ & & \\
1968:Q1 to 1983:Q4 & .53 & $.24^{* *}$ & .07 & .28 & .10 \\
& $(.50)$ & $(.11)$ & $(.19)$ & & \\
1984:Q1 to 2000:Q2 & $.38^{*}$ & $.28^{* *}$ & .22 & .40 & -.02 \\
& $(.22)$ & $(.13)$ & $(.24)$ & & \\
\hline
\end{tabular}

Notes. Newey-West standard errors (computed using a lag truncation parameter of 4) are in parentheses; * and ${ }^{* *}$ denote coefficients that statistically significantly different from zero at the $10 \%$ and $5 \%$ levels. Accell $1_{t}$ equals growth of real output in $t$ minus growth in $t-1$. Accel $2_{t}$ equals growth of real output in $t$ minus average growth in $t-1$ and $t-2$. Accel $3_{t}$ equals growth of real output in $t$ minus a weighted average of growth in $t-1, t-2$, and $t-3$. All accelerations are calculated with current NIPA estimates. 
Table 7A

Efficiency Tests for Revisions to GNP or GDP Growth: Full Sample

\begin{tabular}{|c|c|c|c|c|c|}
\hline & (1) & (2) & (3) & (4) & (5) \\
\hline constant & $\begin{array}{l}.63^{* *} \\
(.15)\end{array}$ & $\begin{array}{l}.63^{* *} \\
(.15)\end{array}$ & $\begin{array}{l}.63^{* *} \\
(.14)\end{array}$ & $\begin{array}{l}.63^{* * *} \\
(.14)\end{array}$ & $\begin{array}{l}.63^{\text {** }} \\
(.14)\end{array}$ \\
\hline advance growth rate & $\cdots$ & $\cdots$ & $\begin{array}{l}-.11 \\
(.08)\end{array}$ & $\begin{array}{l}-.16^{*} \\
(.08)\end{array}$ & $\begin{array}{l}-.20^{*} \\
(.10)\end{array}$ \\
\hline advance acceleration & $\ldots$ & $\ldots$ & $\ldots$ & $\begin{array}{c}.07 \\
(.06)\end{array}$ & $\begin{array}{c}.09 \\
(.06)\end{array}$ \\
\hline percent change in S\&P 500 & $\cdots$ & $\cdots$ & $\cdots$ & .. & $\begin{array}{c}.00 \\
(.01)\end{array}$ \\
\hline 3-month Treasury rate & $\cdots$ & $\cdots$ & $\cdots$ & $\cdots$ & $\begin{array}{l}-.14 \\
(.19)\end{array}$ \\
\hline 10-year Treasury rate & $\cdots$ & $\ldots$ & $\cdots$ & $\cdots$ & $\begin{array}{c}.21 \\
(.27)\end{array}$ \\
\hline consumer sentiment & $\ldots$ & $\cdots$ & $\cdots$ & $\cdots$ & $\begin{array}{c}.01 \\
(.02)\end{array}$ \\
\hline unemployment rate & $\ldots$ & $\ldots$ & $\ldots$ & $\ldots$ & $\begin{array}{l}-.08 \\
(.26)\end{array}$ \\
\hline Q2 dummy & $\ldots$ & $\begin{array}{c}.23 \\
(.48)\end{array}$ & $\begin{array}{c}.20 \\
(.50)\end{array}$ & $\begin{array}{l}.20 \\
(.49)\end{array}$ & $\begin{array}{c}.18 \\
(.50)\end{array}$ \\
\hline Q3 dummy & $\ldots$ & $\begin{array}{c}-1.39^{* * *} \\
(.57)\end{array}$ & $\begin{array}{c}-1.33^{* *} \\
(.53)\end{array}$ & $\begin{array}{c}-1.36^{* *} \\
(.54)\end{array}$ & $\begin{array}{c}-1.34^{* * *} \\
(.54)\end{array}$ \\
\hline Q4 dummy & $\ldots$ & $\begin{array}{l}-.59 \\
(.59)\end{array}$ & $\begin{array}{l}-.61 \\
(.58)\end{array}$ & $\begin{array}{l}-.58 \\
(.57)\end{array}$ & $\begin{array}{l}-.52 \\
(.55)\end{array}$ \\
\hline s.e.e. & 2.13 & 2.06 & 2.03 & 2.03 & 2.06 \\
\hline adjusted $\mathrm{R}^{2}$ & .00 & .07 & .09 & .07 & .07 \\
\hline$\rho$-hat & -.11 & -.11 & -.15 & -.14 & -.14 \\
\hline
\end{tabular}

Notes. Newey-West standard errors (computed using a lag truncation parameter of 4) are in parentheses; * and ${ }^{* *}$ denote coefficients that statistically significantly different from zero at the $10 \%$ and $5 \%$ levels. The dependent variable is the advance-to-current revision to real output growth and the acceleration is growth in $t$ minus the weighted average of growth in $t-1, t-2$, and $t-3$, all as currently measured. The sample range is 1968:Q1 to 2000:Q2 for columns (1) through (5); 1972:Q2 to 2000:Q2 for column (6). 
Table 7B

Efficiency Tests for Revisions to GNP or GDP Growth: Early Sample

\begin{tabular}{|c|c|c|c|c|c|}
\hline & (1) & (2) & (3) & (4) & (5) \\
\hline constant & $\begin{array}{c}.72^{* *} \\
(.28)\end{array}$ & $\begin{array}{l}.72^{* *} \\
(.27)\end{array}$ & $\begin{array}{l}.72^{* *} \\
(.25)\end{array}$ & $\begin{array}{l}.72^{* *} \\
(.24)\end{array}$ & $\begin{array}{l}.72^{* *} \\
(.26)\end{array}$ \\
\hline advance growth rate & $\ldots$ & $\ldots$ & $\begin{array}{l}-.12 \\
(.09)\end{array}$ & $\begin{array}{l}-.16^{*} \\
(.09)\end{array}$ & $\begin{array}{l}-.27^{* *} \\
(.12)\end{array}$ \\
\hline advance acceleration & $\ldots$ & $\ldots$ & $\ldots$ & $\begin{array}{c}.08 \\
(.06)\end{array}$ & $\begin{array}{c}.09 \\
(.06)\end{array}$ \\
\hline percent change in S\&P 500 & $\ldots$ & $\ldots$ & $\ldots$ & $\ldots$ & $\begin{array}{l}.19^{*} \\
(.12)\end{array}$ \\
\hline 3-month Treasury rate & $\ldots$ & $\ldots$ & $\ldots$ & $\ldots$ & $\begin{array}{l}.16 \\
(.43)\end{array}$ \\
\hline 10-year Treasury rate & $\ldots$ & $\ldots$ & $\ldots$ & $\ldots$ & $\begin{array}{l}-.13 \\
(.66)\end{array}$ \\
\hline consumer sentiment & $\ldots$ & $\ldots$ & $\ldots$ & $\ldots$ & $\begin{array}{l}.06 \\
(.04)\end{array}$ \\
\hline unemployment rate & $\ldots$ & $\ldots$ & $\ldots$ & $\ldots$ & $\begin{array}{l}.03 \\
(.45)\end{array}$ \\
\hline Q2 dummy & $\ldots$ & $\begin{array}{l}-.56 \\
(.81)\end{array}$ & $\begin{array}{l}-.52 \\
(.90)\end{array}$ & $\begin{array}{l}-.54 \\
(.90)\end{array}$ & $\begin{array}{l}-.50 \\
(.83)\end{array}$ \\
\hline Q3 dummy & $\ldots$ & $\begin{array}{r}-2.46^{* *} \\
(.96)\end{array}$ & $\begin{array}{c}-2.31^{* *} \\
(.88)\end{array}$ & $\begin{array}{c}-2.35^{* *} \\
(.90)\end{array}$ & $\begin{array}{r}-2.12^{* *} \\
(.89)\end{array}$ \\
\hline Q4 dummy & $\ldots$ & $\begin{array}{r}-1.72^{*} \\
(.91)\end{array}$ & $\begin{array}{r}-1.73^{*} \\
(.91)\end{array}$ & $\begin{array}{r}-1.67^{*} \\
(.89)\end{array}$ & $\begin{array}{r}-1.60^{*} \\
(.86)\end{array}$ \\
\hline s.e.e. & 2.69 & 2.57 & 2.54 & 2.55 & 2.58 \\
\hline adjusted $R^{2}$ & .00 & .09 & .11 & .11 & .08 \\
\hline$\rho$-hat & -.11 & -.11 & -.17 & -.17 & -.17 \\
\hline
\end{tabular}

Notes. Newey-West standard errors (computed using a lag truncation parameter of 4) are in parentheses; * and ${ }^{* *}$ denote coefficients that statistically significantly different from zero at the $10 \%$ and $5 \%$ levels. The dependent variable is the advance-to-current revision to real output growth and the acceleration is growth in $t$ minus the weighted average of growth in $t-1, t-2$, and $t-3$, all as currently measured. The sample range is 1968:Q1 to 1983:Q4 for columns (1) through (5); 1972:Q2 to 1983:Q4 for column (6). 
Table 7C

Efficiency Tests for Revisions to GNP or GDP Growth: Late Sample

\begin{tabular}{|c|c|c|c|c|c|}
\hline & (1) & (2) & (3) & (4) & (5) \\
\hline constant & $\begin{array}{l}.55^{* *} \\
(.14)\end{array}$ & $\begin{array}{l}.55^{* *} \\
(.14)\end{array}$ & $\begin{array}{l}.55^{* *} \\
(.14)\end{array}$ & $\begin{array}{l}.55^{* *} \\
(.14)\end{array}$ & $\begin{array}{c}.55^{* *} \\
(.12)\end{array}$ \\
\hline advance growth rate & ... & $\ldots$ & $\begin{array}{l}-.06 \\
(.08)\end{array}$ & $\begin{array}{l}-.08 \\
(.08)\end{array}$ & $\begin{array}{l}-.48^{* *} \\
(.10)\end{array}$ \\
\hline advance acceleration & $\cdots$ & .. & $\cdots$ & $\begin{array}{c}.03 \\
(.08)\end{array}$ & $\begin{array}{c}.29^{* *} \\
(.12)\end{array}$ \\
\hline percent change in S\&P 500 & $\cdots$ & .. & $\ldots$ & $\cdots$ & $\begin{array}{l}-.02^{* *} \\
(.01)\end{array}$ \\
\hline 3-month Treasury rate & .. & .. & $\cdots$ & $\cdots$ & $\begin{array}{l}-.57^{* *} \\
(.18)\end{array}$ \\
\hline 10-year Treasury rate & $\cdots$ & $\ldots$ & .. & $\ldots$ & $\begin{array}{c}.62^{* *} \\
(.17)\end{array}$ \\
\hline consumer sentiment & $\ldots$ & $\cdots$ & ... & $\ldots$ & $\begin{array}{c}.09^{* *} \\
(.03)\end{array}$ \\
\hline unemployment rate & $\ldots$ & $\ldots$ & $\ldots$ & $\ldots$ & $\begin{array}{l}-.09 \\
(.18)\end{array}$ \\
\hline Q2 dummy & $\ldots$ & $\begin{array}{l}.96^{* *} \\
(.44)\end{array}$ & $\begin{array}{c}.91^{* *} \\
(.46)\end{array}$ & $\begin{array}{c}.93^{* *} \\
(.44)\end{array}$ & $\begin{array}{c}.56 \\
(.42)\end{array}$ \\
\hline Q3 dummy & $\ldots$ & $\begin{array}{l}-.36 \\
(.48)\end{array}$ & $\begin{array}{l}-.37 \\
(.46)\end{array}$ & $\begin{array}{l}-.38 \\
(.46)\end{array}$ & $\begin{array}{l}-.71^{*} \\
(.39)\end{array}$ \\
\hline Q4 dummy & $\ldots$ & $\begin{array}{c}.51 \\
(.56)\end{array}$ & $\begin{array}{c}.50 \\
(.56)\end{array}$ & $\begin{array}{c}.50 \\
(.56)\end{array}$ & $\begin{array}{c}.30 \\
(.49)\end{array}$ \\
\hline s.e.e. & 1.39 & 1.33 & 1.33 & 1.34 & 1.26 \\
\hline adjusted $\mathrm{R}^{2}$ & .00 & .09 & .08 & .07 & .18 \\
\hline$\rho$-hat & -.15 & -.05 & -.04 & -.04 & -.18 \\
\hline
\end{tabular}

Notes. Newey-West standard errors (computed using a lag truncation parameter of 4) are in parentheses; ${ }^{*}$ and ${ }^{* *}$ denote coefficients that statistically significantly different from zero at the $10 \%$ and $5 \%$ levels. The dependent variable is the advance-to-current revision to real output growth and the acceleration is growth in $t$ minus the weighted average of growth in $t-1, t-2$, and $t-3$, all as currently measured. The sample range is 1984:Q1 to 2000:Q2 for all columns. 
Table A1

Effect of Accelerations on Revisions to Growth of GNP or GDP Components

\begin{tabular}{|c|c|c|c|c|c|}
\hline & constant & accel. & $\begin{array}{c}\text { accel. } \mathrm{x} \\
(\text { accel. }>0)\end{array}$ & $\mathrm{R}^{2}$ & $\hat{\rho}$ \\
\hline \multicolumn{6}{|c|}{ Consumer expenditures } \\
\hline $1969: 4$ to $2000: 2$ & $\begin{array}{l}-.09 \\
(.17)\end{array}$ & $\begin{array}{l}-.19^{*} \\
(.11)\end{array}$ & $\begin{array}{l}.33^{* *} \\
(.15)\end{array}$ & .04 & .06 \\
\hline $1969: 4$ to $1983: 4$ & $\begin{array}{l}-.29 \\
(.32)\end{array}$ & $\begin{array}{l}-.17 \\
(.15)\end{array}$ & $\begin{array}{l}.29 \\
(.19)\end{array}$ & .04 & .03 \\
\hline $1984: 1$ to $2000: 2$ & $\begin{array}{l}-.16 \\
(.17) \\
\end{array}$ & $\begin{array}{l}-.35^{* *} \\
(.14) \\
\end{array}$ & $\begin{array}{l}.67^{* *} \\
(.26) \\
\end{array}$ & .12 & .01 \\
\hline \multicolumn{6}{|c|}{ Consumer durables } \\
\hline $1969: 4$ to $2000: 2$ & $\begin{array}{l}-.19 \\
(.69)\end{array}$ & $\begin{array}{l}-.04 \\
(.04)\end{array}$ & $\begin{array}{l}.10 \\
(.07)\end{array}$ & .02 & -.06 \\
\hline $1969: 4$ to $1983: 4$ & $\begin{array}{c}.36 \\
(1.09)\end{array}$ & $\begin{array}{l}-.03 \\
(.07)\end{array}$ & $\begin{array}{c}.04 \\
(.10)\end{array}$ & .00 & -.05 \\
\hline $1984: 1$ to $2000: 2$ & $\begin{array}{r}-1.21 \\
(.80)\end{array}$ & $\begin{array}{l}-.07 \\
(.05)\end{array}$ & $\begin{array}{l}.27^{* *} \\
(.11)\end{array}$ & .09 & -.10 \\
\hline \multicolumn{6}{|c|}{ Consumer nondurables } \\
\hline $1969: 4$ to $2000: 2$ & $\begin{array}{l}.59 \\
(.44)\end{array}$ & $\begin{array}{l}.03 \\
(.17)\end{array}$ & $\begin{array}{l}-.04 \\
(.26)\end{array}$ & .00 & .14 \\
\hline $1969: 4$ to $1983: 4$ & $\begin{array}{l}-.43 \\
(.50)\end{array}$ & $\begin{array}{l}-.06 \\
(.22)\end{array}$ & $\begin{array}{l}.15 \\
(.34)\end{array}$ & .01 & -.16 \\
\hline $1984: 1$ to $2000: 2$ & $\begin{array}{l}1.24^{* *} \\
(.57)\end{array}$ & $\begin{array}{l}.00 \\
(.20)\end{array}$ & $\begin{array}{l}-.02 \\
(.32)\end{array}$ & .00 & .19 \\
\hline \multicolumn{6}{|l|}{ Consumer services } \\
\hline $1969: 4$ to $2000: 2$ & $\begin{array}{c}.37 \\
(.24)\end{array}$ & $\begin{array}{l}.61^{* *} \\
(.11)\end{array}$ & $\begin{array}{l}-.33 \\
(.20)\end{array}$ & .28 & .20 \\
\hline $1969: 4$ to $1983: 4$ & $\begin{array}{l}.71^{*} \\
(.43)\end{array}$ & $\begin{array}{l}.73^{* *} \\
(.16)\end{array}$ & $\begin{array}{l}-.51 \\
(.31)\end{array}$ & .32 & .09 \\
\hline $1984: 1$ to $2000: 2$ & $\begin{array}{l}.15 \\
(.23)\end{array}$ & $\begin{array}{l}.51^{* *} \\
(.15)\end{array}$ & $\begin{array}{l}-.20 \\
(.25)\end{array}$ & .23 & .32 \\
\hline
\end{tabular}

Notes. Newey-West standard errors (computed using a lag truncation parameter of 4) are in parentheses; ${ }^{*}$ and ${ }^{* *}$ denote coefficients that statistically significantly different from zero at the $10 \%$ and $5 \%$ levels. The dependent variable is the advance-to-current revision to growth in the component, and the acceleration is growth in the component in $t$ minus the weighted average of growth in $t-1, t-2$, and $t-3$, all as currently measured. 
Table A2 (continued)

Effect of Accelerations on Revisions to Growth of GNP or GDP Components

\begin{tabular}{|c|c|c|c|c|c|}
\hline & constant & accel. & $\begin{array}{c}\text { accel. x } \\
\text { (accel. > 0) }\end{array}$ & $\mathrm{R}^{2}$ & $\hat{\rho}$ \\
\hline \multicolumn{6}{|c|}{ Business fixed investment } \\
\hline $1969: 4$ to $2000: 2$ & $\begin{array}{c}.40 \\
(1.07)\end{array}$ & $\begin{array}{l}.02 \\
(.16)\end{array}$ & $\begin{array}{c}.21 \\
(.27)\end{array}$ & .04 & .17 \\
\hline $1969: 4$ to $1983: 4$ & $\begin{array}{c}2.77 \\
(1.73)\end{array}$ & $\begin{array}{l}.22 \\
(.22)\end{array}$ & $\begin{array}{l}-.01 \\
(.36)\end{array}$ & .11 & .29 \\
\hline $1984: 1$ to $2000: 2$ & $\begin{array}{l}-.86 \\
(.99)\end{array}$ & $\begin{array}{l}-.11 \\
(.17)\end{array}$ & $\begin{array}{l}.16 \\
(.24)\end{array}$ & .01 & .02 \\
\hline \multicolumn{6}{|c|}{ Inventory investment (contribution to GDP growth) } \\
\hline $1969: 4$ to $2000: 2$ & $\begin{array}{l}-.22 \\
(.24)\end{array}$ & $\begin{array}{l}.11 \\
(.19)\end{array}$ & $\begin{array}{c}.25 \\
(.28)\end{array}$ & .11 & -.28 \\
\hline $1969: 4$ to $1983: 4$ & $\begin{array}{l}-.25 \\
(.34)\end{array}$ & $\begin{array}{l}.09 \\
(.28)\end{array}$ & $\begin{array}{l}.34 \\
(.34)\end{array}$ & .14 & -.25 \\
\hline $1984: 1$ to $2000: 2$ & $\begin{array}{l}-.07 \\
(.32) \\
\end{array}$ & $\begin{array}{l}.19 \\
(.21) \\
\end{array}$ & $\begin{array}{l}-.02 \\
(.43)\end{array}$ & .06 & -.32 \\
\hline \multicolumn{6}{|c|}{ Residential investment } \\
\hline $1969: 4$ to $2000: 2$ & $\begin{array}{c}-.56 \\
(1.15)\end{array}$ & $\begin{array}{l}.06 \\
(.11)\end{array}$ & $\begin{array}{l}.12 \\
(.15)\end{array}$ & .08 & -.05 \\
\hline $1969: 4$ to $1983: 4$ & $\begin{array}{c}1.26 \\
(2.59)\end{array}$ & $\begin{array}{l}.12 \\
(.17)\end{array}$ & $\begin{array}{c}.03 \\
(.22)\end{array}$ & .09 & -.07 \\
\hline $1984: 1$ to $2000: 2$ & $\begin{array}{c}-.71 \\
(1.01) \\
\end{array}$ & $\begin{array}{l}.09 \\
(.12) \\
\end{array}$ & $\begin{array}{l}-.04 \\
(.20) \\
\end{array}$ & .02 & .14 \\
\hline \multicolumn{6}{|l|}{ Government } \\
\hline $1969: 4$ to $2000: 2$ & $\begin{array}{l}.73 \\
(.85)\end{array}$ & $\begin{array}{l}.49^{* *} \\
(.22)\end{array}$ & $\begin{array}{l}-.43 \\
(.38)\end{array}$ & .08 & .02 \\
\hline $1969: 4$ to $1983: 4$ & $\begin{array}{c}-.99 \\
(1.11)\end{array}$ & $\begin{array}{l}.34^{*} \\
(.17)\end{array}$ & $\begin{array}{c}.17 \\
(.42)\end{array}$ & .15 & .19 \\
\hline $1984: 1$ to $2000: 2$ & $\begin{array}{l}2.39^{* *} \\
(1.12)\end{array}$ & $\begin{array}{l}.65 \\
(.41)\end{array}$ & $\begin{array}{r}-1.00 \\
(.61)\end{array}$ & .10 & -.17 \\
\hline
\end{tabular}

Notes. Newey-West standard errors (computed using a lag truncation parameter of 4) are in parentheses; ${ }^{*}$ and ${ }^{* *}$ denote coefficients that statistically significantly different from zero at the $10 \%$ and $5 \%$ levels. The dependent variable is the advance-to-current revision to growth in the component, and the acceleration is growth in the component in $t$ minus the weighted average of growth in $t-1, t-2$, and $t-3$, all as currently measured. 
Table A1 (continued)

Effect of Accelerations on Revisions to Growth of GNP or GDP Components

\begin{tabular}{|c|c|c|c|c|c|}
\hline & constant & accel. & $\begin{array}{c}\text { accel. } \mathrm{x} \\
(\text { accel. }>0) \\
\end{array}$ & $\mathrm{R}^{2}$ & $\hat{\rho}$ \\
\hline \multicolumn{6}{|l|}{ Exports } \\
\hline $1969: 4$ to $2000: 2$ & $\begin{array}{l}4.18^{* *} \\
(.93)\end{array}$ & $\begin{array}{l}.19^{* *} \\
(.07)\end{array}$ & $\begin{array}{l}-.19 \\
(.16)\end{array}$ & .04 & -.04 \\
\hline $1969: 4$ to $1983: 4$ & $\begin{array}{l}5.41^{* *} \\
(1.54)\end{array}$ & $\begin{array}{l}.20^{* *} \\
(.08)\end{array}$ & $\begin{array}{l}-.25 \\
(.18)\end{array}$ & .04 & -.08 \\
\hline $1984: 1$ to $2000: 2$ & $\begin{array}{l}3.30^{* *} \\
(1.16) \\
\end{array}$ & $\begin{array}{c}.25 \\
(.17) \\
\end{array}$ & $\begin{array}{l}-.14 \\
(.26) \\
\end{array}$ & .09 & .05 \\
\hline \multicolumn{6}{|l|}{ Imports } \\
\hline $1969: 4$ to $2000: 2$ & $\begin{array}{c}.25 \\
(1.31)\end{array}$ & $\begin{array}{l}.21 \\
(.16)\end{array}$ & $\begin{array}{l}-.09 \\
(.18)\end{array}$ & .07 & -.29 \\
\hline $1969: 4$ to $1983: 4$ & $\begin{array}{l}-1.33 \\
(2.53)\end{array}$ & $\begin{array}{l}.04 \\
(.12)\end{array}$ & $\begin{array}{l}.11 \\
(.19)\end{array}$ & .09 & .05 \\
\hline $1984: 1$ to $2000: 2$ & $\begin{array}{c}3.40^{*} \\
(2.13)\end{array}$ & $\begin{array}{l}.84^{* *} \\
(.39)\end{array}$ & $\begin{array}{l}-.95^{*} \\
(.53)\end{array}$ & .16 & -.49 \\
\hline
\end{tabular}

Notes. Newey-West standard errors (computed using a lag truncation parameter of 4) are in parentheses; ${ }^{*}$ and ${ }^{* *}$ denote coefficients that statistically significantly different from zero at the $10 \%$ and $5 \%$ levels. The dependent variable is the advance-to-current revision to growth in the component, and the acceleration is growth in the component in $t$ minus the weighted average of growth in $t-1, t-2$, and $t-3$, all as currently measured. 
Table A2

Efficiency Tests on Components of GNP or GDP

\begin{tabular}{|c|c|c|c|c|c|c|}
\hline & \multicolumn{3}{|c|}{ Consumer expenditures } & \multicolumn{3}{|c|}{ Consumer durables } \\
\hline & full & early & late & full & early & late \\
\hline constant & $\begin{array}{l}.28^{* *} \\
(.11)\end{array}$ & $\begin{array}{l}.11 \\
(.12)\end{array}$ & $\begin{array}{l}.43^{* *} \\
(.12)\end{array}$ & $\begin{array}{l}.43 \\
(.35)\end{array}$ & $\begin{array}{l}.64^{*} \\
(.37)\end{array}$ & $\begin{array}{l}.25 \\
(.41)\end{array}$ \\
\hline $\begin{array}{l}\text { advance growth } \\
\text { rate }\end{array}$ & $\begin{array}{l}-.22^{* *} \\
(.08)\end{array}$ & $\begin{array}{l}-.45^{* *} \\
(.05)\end{array}$ & $\begin{array}{l}-.28 \\
(.23)\end{array}$ & $\begin{array}{l}-.08 \\
(.07)\end{array}$ & $\begin{array}{l}-.15 \\
(.10)\end{array}$ & $\begin{array}{l}-.27^{*} \\
(.15)\end{array}$ \\
\hline $\begin{array}{l}\text { advance } \\
\text { acceleration }\end{array}$ & $\begin{array}{l}-.08 \\
(.06)\end{array}$ & $\begin{array}{l}.05 \\
(.04)\end{array}$ & $\begin{array}{l}-.07 \\
(.18)\end{array}$ & $\begin{array}{l}-.02 \\
(.05)\end{array}$ & $\begin{array}{l}.00 \\
(.07)\end{array}$ & $\begin{array}{l}.14 \\
(.12)\end{array}$ \\
\hline $\begin{array}{l}\text { percent change } \\
\text { in } S \& P 500\end{array}$ & $\begin{array}{l}.01^{*} \\
(.01)\end{array}$ & $\begin{array}{l}.02^{* *} \\
(.01)\end{array}$ & $\begin{array}{l}-.00 \\
(.01)\end{array}$ & $\begin{array}{l}-.00 \\
(.02)\end{array}$ & $\begin{array}{l}.03 \\
(.02)\end{array}$ & $\begin{array}{l}-.04 \\
(.04)\end{array}$ \\
\hline $\begin{array}{l}\text { 3-month } \\
\text { Treasury rate }\end{array}$ & $\begin{array}{l}-.33^{* *} \\
(.14)\end{array}$ & $\begin{array}{l}-.07 \\
(.20)\end{array}$ & $\begin{array}{l}-.65^{* *} \\
(.22)\end{array}$ & $\begin{array}{l}-.17 \\
(.44)\end{array}$ & $\begin{array}{l}-.34 \\
(.71)\end{array}$ & $\begin{array}{l}-.36 \\
(.77)\end{array}$ \\
\hline $\begin{array}{l}\text { 10-year } \\
\text { Treasury rate }\end{array}$ & $\begin{array}{l}.25 \\
(.18)\end{array}$ & $\begin{array}{l}-.05 \\
(.29)\end{array}$ & $\begin{array}{l}-.63^{* *} \\
(.25)\end{array}$ & $\begin{array}{l}-.05 \\
(.56)\end{array}$ & $\begin{array}{l}.11 \\
(.96)\end{array}$ & $\begin{array}{c}.05 \\
(.81)\end{array}$ \\
\hline $\begin{array}{l}\text { consumer } \\
\text { sentiment }\end{array}$ & $\begin{array}{c}.02^{*} \\
(.01)\end{array}$ & $\begin{array}{l}.10^{* *} \\
(.02)\end{array}$ & $\begin{array}{l}.05 \\
(.05)\end{array}$ & $\begin{array}{l}.10^{* *} \\
(.05)\end{array}$ & $\begin{array}{l}.17 \\
(.11)\end{array}$ & $\begin{array}{l}.30^{* * *} \\
(.09)\end{array}$ \\
\hline $\begin{array}{l}\text { unemployment } \\
\text { rate }\end{array}$ & $\begin{array}{c}.06 \\
(.16)\end{array}$ & $\begin{array}{l}.12 \\
(.19)\end{array}$ & $\begin{array}{l}-.22 \\
(.31)\end{array}$ & $\begin{array}{l}.84^{*} \\
(.47)\end{array}$ & $\begin{array}{l}.39 \\
(.56)\end{array}$ & $\begin{array}{l}1.65^{\text {** }} \\
(.81)\end{array}$ \\
\hline Q2 dummy & $\begin{array}{l}.19 \\
(.28)\end{array}$ & $\begin{array}{l}-.15 \\
(.32)\end{array}$ & $\begin{array}{l}.19 \\
(.40)\end{array}$ & $\begin{array}{c}1.80 \\
(1.38)\end{array}$ & $\begin{array}{c}2.09 \\
(1.74)\end{array}$ & $\begin{array}{c}1.11 \\
(1.92)\end{array}$ \\
\hline Q3 dummy & $\begin{array}{c}.22 \\
(.32)\end{array}$ & $\begin{array}{l}.10 \\
(.35)\end{array}$ & $\begin{array}{l}.15 \\
(.48)\end{array}$ & $\begin{array}{c}2.07 \\
(1.29)\end{array}$ & $\begin{array}{c}3.51^{* *} \\
(1.19)\end{array}$ & $\begin{array}{c}.56 \\
(1.90)\end{array}$ \\
\hline Q4 dummy & $\begin{array}{l}.58^{*} \\
(.30)\end{array}$ & $\begin{array}{l}.32 \\
(.46)\end{array}$ & $\begin{array}{l}.41 \\
(.35)\end{array}$ & $\begin{array}{c}1.91 \\
(1.15)\end{array}$ & $\begin{array}{c}1.76 \\
(1.85)\end{array}$ & $\begin{array}{c}1.91 \\
(1.50)\end{array}$ \\
\hline s.e.e. & 1.28 & 1.28 & 1.15 & 4.91 & 5.24 & 4.63 \\
\hline benchmark s.e.e. & 1.61 & 1.81 & 1.41 & 5.13 & 5.64 & 4.67 \\
\hline adjusted $\mathrm{R}^{2}$ & .39 & .50 & .33 & .08 & .14 & .01 \\
\hline
\end{tabular}

Notes. Newey-West standard errors (computed using a lag truncation parameter of 4) are in parentheses; ${ }^{*}$ and ${ }^{* *}$ denote coefficients that statistically significantly different from zero at the $10 \%$ and $5 \%$ levels. The dependent variable is the advance-to-current revision to real output growth and the acceleration is growth in $t$ minus the weighted average of growth in $t-1, t-2$, and $t-3$, all as currently measured. The benchmark standard error of the estimate is the standard error when only a constant is included on the right-hand-side. 
Table A2 (continued)

Efficiency Tests on Components of GNP or GDP

\begin{tabular}{|c|c|c|c|c|c|c|}
\hline & \multicolumn{3}{|c|}{ Consumer nondurables } & \multicolumn{3}{|c|}{ Consumer services } \\
\hline & full & early & late & full & early & late \\
\hline constant & $\begin{array}{l}.54^{* *} \\
(.16)\end{array}$ & $\begin{array}{l}-.24 \\
(.24)\end{array}$ & $\begin{array}{l}1.23^{* *} \\
(.16)\end{array}$ & $\begin{array}{l}.15 \\
(.16)\end{array}$ & $\begin{array}{l}.27^{* *} \\
(.12)\end{array}$ & $\begin{array}{l}.03 \\
(.11)\end{array}$ \\
\hline $\begin{array}{l}\text { advance growth } \\
\text { rate }\end{array}$ & $\begin{array}{l}-.44^{* *} \\
(.10)\end{array}$ & $\begin{array}{l}-.27^{* *} \\
(.10)\end{array}$ & $\begin{array}{l}-.66^{* *} \\
(.14)\end{array}$ & $\begin{array}{l}-.39^{* *} \\
(.17)\end{array}$ & $\begin{array}{l}-.91^{* * *} \\
(.16)\end{array}$ & $\begin{array}{l}-.24 \\
(.18)\end{array}$ \\
\hline $\begin{array}{l}\text { advance } \\
\text { acceleration }\end{array}$ & $\begin{array}{l}-.04 \\
(.07)\end{array}$ & $\begin{array}{l}-.13^{*} \\
(.07)\end{array}$ & $\begin{array}{l}.14 \\
(.10)\end{array}$ & $\begin{array}{c}.00 \\
(.15)\end{array}$ & $\begin{array}{l}.29^{* *} \\
(.11)\end{array}$ & $\begin{array}{l}-.14 \\
(.20)\end{array}$ \\
\hline $\begin{array}{l}\text { percent change } \\
\text { in } S \& P 500\end{array}$ & $\begin{array}{l}.02^{*} \\
(.01)\end{array}$ & $\begin{array}{l}.03^{* *} \\
(.01)\end{array}$ & $\begin{array}{l}-.00 \\
(.01)\end{array}$ & $\begin{array}{c}.01 \\
(.01)\end{array}$ & $\begin{array}{l}.02^{* *} \\
(.00)\end{array}$ & $\begin{array}{c}.00 \\
(.01)\end{array}$ \\
\hline $\begin{array}{l}\text { 3-month } \\
\text { Treasury rate }\end{array}$ & $\begin{array}{l}-.42^{*} \\
(.22)\end{array}$ & $\begin{array}{l}-.23 \\
(.23)\end{array}$ & $\begin{array}{l}-.62^{* *} \\
(.29)\end{array}$ & $\begin{array}{l}-.20 \\
(.17)\end{array}$ & $\begin{array}{c}.07 \\
(.18)\end{array}$ & $\begin{array}{l}-.63^{* *} \\
(.24)\end{array}$ \\
\hline $\begin{array}{l}\text { 10-year } \\
\text { Treasury rate }\end{array}$ & $\begin{array}{l}.42 \\
(.28)\end{array}$ & $\begin{array}{l}.36 \\
(.32)\end{array}$ & $\begin{array}{l}.46 \\
(.34)\end{array}$ & $\begin{array}{c}.07 \\
(.24)\end{array}$ & $\begin{array}{l}-.32 \\
(.24)\end{array}$ & $\begin{array}{l}.63^{* *} \\
(.28)\end{array}$ \\
\hline $\begin{array}{l}\text { consumer } \\
\text { sentiment }\end{array}$ & $\begin{array}{l}.03 \\
(.02)\end{array}$ & $\begin{array}{l}.06^{* * *} \\
(.03)\end{array}$ & $\begin{array}{c}.06 \\
(.06)\end{array}$ & $\begin{array}{c}.03 \\
(.02)\end{array}$ & $\begin{array}{l}.10^{* *} \\
(.02)\end{array}$ & $\begin{array}{l}.07^{*} \\
(.02)\end{array}$ \\
\hline $\begin{array}{l}\text { unemployment } \\
\text { rate }\end{array}$ & $\begin{array}{l}-.28 \\
(.20)\end{array}$ & $\begin{array}{l}-.32 \\
(.26)\end{array}$ & $\begin{array}{l}-.49 \\
(.42)\end{array}$ & $\begin{array}{c}.29 \\
(.21)\end{array}$ & $\begin{array}{c}.18 \\
(.17)\end{array}$ & $\begin{array}{c}.13 \\
(.25)\end{array}$ \\
\hline Q2 dummy & $\begin{array}{c}.08 \\
(.41)\end{array}$ & $\begin{array}{l}-.38 \\
(.64)\end{array}$ & $\begin{array}{c}.51 \\
(.37)\end{array}$ & $\begin{array}{l}-.02 \\
(.31)\end{array}$ & $\begin{array}{l}-.10 \\
(.37)\end{array}$ & $\begin{array}{l}-.08 \\
(.40)\end{array}$ \\
\hline Q3 dummy & $\begin{array}{c}.06 \\
(.47)\end{array}$ & $\begin{array}{c}.12 \\
(.59)\end{array}$ & $\begin{array}{l}-.06 \\
(.51)\end{array}$ & $\begin{array}{l}-.09 \\
(.33)\end{array}$ & $\begin{array}{l}-.40 \\
(.41)\end{array}$ & $\begin{array}{c}.21 \\
(.43)\end{array}$ \\
\hline Q4 dummy & $\begin{array}{c}.21 \\
(.39)\end{array}$ & $\begin{array}{l}-.73 \\
(.47)\end{array}$ & $\begin{array}{c}.66 \\
(.46)\end{array}$ & $\begin{array}{c}.68^{*} \\
(.37)\end{array}$ & $\begin{array}{l}1.03^{* *} \\
(.46)\end{array}$ & $\begin{array}{c}.30 \\
(.49)\end{array}$ \\
\hline s.e.e. & 1.67 & 1.77 & 1.41 & 1.45 & 1.31 & 1.18 \\
\hline benchmark s.e.e. & 2.40 & 2.31 & 2.23 & 1.65 & 1.94 & 1.37 \\
\hline adjusted $\mathrm{R}^{2}$ & .52 & .42 & .61 & .24 & .54 & .26 \\
\hline
\end{tabular}

Notes. Newey-West standard errors (computed using a lag truncation parameter of 4) are in parentheses; ${ }^{*}$ and ${ }^{* *}$ denote coefficients that statistically significantly different from zero at the $10 \%$ and $5 \%$ levels. The dependent variable is the advance-to-current revision to real output growth and the acceleration is growth in $t$ minus the weighted average of growth in $t-1, t-2$, and $t-3$, all as currently measured. The benchmark standard error of the estimate is the standard error when only a constant is included on the right-hand-side. 
Table A2 (continued)

Efficiency Tests on Components of GNP or GDP

\begin{tabular}{|c|c|c|c|c|c|c|}
\hline & \multicolumn{3}{|c|}{ Business fixed investment } & \multicolumn{3}{|c|}{ Change in inventories } \\
\hline & full & early & late & full & early & late \\
\hline constant & $\begin{array}{l}1.13^{* *} \\
(.57)\end{array}$ & $\begin{array}{l}2.86^{* *} \\
(.81)\end{array}$ & $\begin{array}{l}-.39 \\
(.55)\end{array}$ & $\begin{array}{c}.03 \\
(.08)\end{array}$ & $\begin{array}{l}.17 \\
(.13)\end{array}$ & $\begin{array}{l}-.09 \\
(.10)\end{array}$ \\
\hline $\begin{array}{l}\text { advance growth } \\
\text { rate }\end{array}$ & $\begin{array}{l}.03 \\
(.12)\end{array}$ & $\begin{array}{l}.19 \\
(.22)\end{array}$ & $\begin{array}{l}-.21 \\
(.13)\end{array}$ & $\begin{array}{l}-.48^{* *} \\
(.12)\end{array}$ & $\begin{array}{l}-.43^{* *} \\
(.14)\end{array}$ & $\begin{array}{l}-.55^{* *} \\
(.18)\end{array}$ \\
\hline $\begin{array}{l}\text { advance } \\
\text { acceleration }\end{array}$ & $\begin{array}{l}-.23^{* *} \\
(.09)\end{array}$ & $\begin{array}{l}-.29^{* *} \\
(.14)\end{array}$ & $\begin{array}{l}-.14 \\
(.10)\end{array}$ & $\begin{array}{l}-.01 \\
(.08)\end{array}$ & $\begin{array}{l}-.05 \\
(.10)\end{array}$ & $\begin{array}{l}.12 \\
(.14)\end{array}$ \\
\hline $\begin{array}{l}\text { percent change } \\
\text { in } S \& P 500\end{array}$ & $\begin{array}{l}.02 \\
(.02)\end{array}$ & $\begin{array}{l}.05^{*} \\
(.03)\end{array}$ & $\begin{array}{c}.02 \\
(.02)\end{array}$ & $\begin{array}{l}-.01 \\
(.01)\end{array}$ & $\begin{array}{l}-.00 \\
(.01)\end{array}$ & $\begin{array}{l}-.03^{* *} \\
(.01)\end{array}$ \\
\hline $\begin{array}{l}\text { 3-month } \\
\text { Treasury rate }\end{array}$ & $\begin{array}{c}.92 \\
(.56)\end{array}$ & $\begin{array}{l}-.31 \\
(.98)\end{array}$ & $\begin{array}{c}-.77 \\
(1.05)\end{array}$ & $\begin{array}{l}-.01 \\
(.17)\end{array}$ & $\begin{array}{c}.09 \\
(.29)\end{array}$ & $\begin{array}{l}-.11 \\
(.17)\end{array}$ \\
\hline $\begin{array}{l}\text { 10-year } \\
\text { Treasury rate }\end{array}$ & $\begin{array}{l}-.73 \\
(.82)\end{array}$ & $\begin{array}{c}1.36 \\
(1.42)\end{array}$ & $\begin{array}{c}.54 \\
(1.17)\end{array}$ & $\begin{array}{l}-.00 \\
(.19)\end{array}$ & $\begin{array}{l}-.07 \\
(.35)\end{array}$ & $\begin{array}{l}.05 \\
(.22)\end{array}$ \\
\hline $\begin{array}{l}\text { consumer } \\
\text { sentiment }\end{array}$ & $\begin{array}{l}-.01 \\
(.07)\end{array}$ & $\begin{array}{l}.02 \\
(.15)\end{array}$ & $\begin{array}{l}.13 \\
(.09)\end{array}$ & $\begin{array}{c}.01 \\
(.01)\end{array}$ & $\begin{array}{c}.03 \\
(.02)\end{array}$ & $\begin{array}{l}.04^{* *} \\
(.02)\end{array}$ \\
\hline $\begin{array}{l}\text { unemployment } \\
\text { rate }\end{array}$ & $\begin{array}{l}.32 \\
(.79)\end{array}$ & $\begin{array}{l}-1.25 \\
(1.36)\end{array}$ & $\begin{array}{c}-.40 \\
(1.31)\end{array}$ & $\begin{array}{l}.12 \\
(.15)\end{array}$ & $\begin{array}{c}.05 \\
(.25)\end{array}$ & $\begin{array}{l}.18 \\
(.19)\end{array}$ \\
\hline Q2 dummy & $\begin{array}{c}1.64 \\
(1.32)\end{array}$ & $\begin{array}{c}4.01^{*} \\
(2.05)\end{array}$ & $\begin{array}{c}-.01 \\
(1.59)\end{array}$ & $\begin{array}{c}.01 \\
(.44)\end{array}$ & $\begin{array}{l}-.54 \\
(.77)\end{array}$ & $\begin{array}{c}.62 \\
(.47)\end{array}$ \\
\hline Q3 dummy & $\begin{array}{c}2.16 \\
(1.30)\end{array}$ & $\begin{array}{c}5.39^{* *} \\
(1.80)\end{array}$ & $\begin{array}{c}-.30 \\
(1.40)\end{array}$ & $\begin{array}{l}-.72^{*} \\
(.41)\end{array}$ & $\begin{array}{r}-1.15^{*} \\
(.67)\end{array}$ & $\begin{array}{l}-.37 \\
(.42)\end{array}$ \\
\hline Q4 dummy & $\begin{array}{c}3.77^{* *} \\
(1.33)\end{array}$ & $\begin{array}{l}6.16^{* *} \\
(1.92)\end{array}$ & $\begin{array}{c}1.86 \\
(1.32)\end{array}$ & $\begin{array}{l}-.35 \\
(.48)\end{array}$ & $\begin{array}{r}-1.48^{*} \\
(.77)\end{array}$ & $\begin{array}{c}.57 \\
(.44)\end{array}$ \\
\hline s.e.e. & 5.46 & 5.98 & 4.30 & 1.52 & 1.88 & 1.07 \\
\hline benchmark s.e.e. & 5.98 & 6.58 & 4.97 & 1.82 & 2.16 & 1.48 \\
\hline adjusted $\mathrm{R}^{2}$ & .17 & .18 & .25 & .31 & .24 & .48 \\
\hline
\end{tabular}

Notes. Newey-West standard errors (computed using a lag truncation parameter of 4) are in parentheses; ${ }^{*}$ and ${ }^{* *}$ denote coefficients that statistically significantly different from zero at the $10 \%$ and $5 \%$ levels. The dependent variable is the advance-to-current revision to real output growth and the acceleration is growth in $t$ minus the weighted average of growth in $t-1, t-2$, and $t-3$, all as currently measured. The benchmark standard error of the estimate is the standard error when only a constant is included on the right-hand-side. 
Table A2 (continued)

Efficiency Tests on Components of GNP or GDP

\begin{tabular}{|c|c|c|c|c|c|c|}
\hline & \multicolumn{3}{|c|}{ Residential investment } & \multicolumn{3}{|c|}{ Government } \\
\hline & full & early & late & full & early & late \\
\hline constant & $\begin{array}{l}.39 \\
(.59)\end{array}$ & $\begin{array}{c}1.90^{*} \\
(1.03)\end{array}$ & $\begin{array}{l}-.92^{* *} \\
(.49)\end{array}$ & $\begin{array}{l}.04 \\
(.26)\end{array}$ & $\begin{array}{l}-.71^{*} \\
(.37)\end{array}$ & $\begin{array}{l}.70^{* * *} \\
(.23)\end{array}$ \\
\hline $\begin{array}{l}\text { advance growth } \\
\text { rate }\end{array}$ & $\begin{array}{l}-.02 \\
(.06)\end{array}$ & $\begin{array}{l}-.15^{*} \\
(.08)\end{array}$ & $\begin{array}{l}.01 \\
(.13)\end{array}$ & $\begin{array}{l}-.66^{* *} \\
(.09)\end{array}$ & $\begin{array}{l}-.79^{* *} \\
(.11)\end{array}$ & $\begin{array}{l}-.74^{* *} \\
(.13)\end{array}$ \\
\hline $\begin{array}{l}\text { advance } \\
\text { acceleration }\end{array}$ & $\begin{array}{l}-.19^{* *} \\
(.05)\end{array}$ & $\begin{array}{l}-.12 \\
(.08)\end{array}$ & $\begin{array}{l}-.20^{* *} \\
(.08)\end{array}$ & $\begin{array}{l}.03 \\
(.07)\end{array}$ & $\begin{array}{l}.16 \\
(.10)\end{array}$ & $\begin{array}{c}.09 \\
(.07)\end{array}$ \\
\hline $\begin{array}{l}\text { percent change } \\
\text { in } S \& P 500\end{array}$ & $\begin{array}{l}.09^{* *} \\
(.04)\end{array}$ & $\begin{array}{l}.14^{* *} \\
(.06)\end{array}$ & $\begin{array}{l}.04 \\
(.04)\end{array}$ & $\begin{array}{l}.02 \\
(.01)\end{array}$ & $\begin{array}{l}-.00 \\
(.02)\end{array}$ & $\begin{array}{c}.02 \\
(.01)\end{array}$ \\
\hline $\begin{array}{l}\text { 3-month } \\
\text { Treasury rate }\end{array}$ & $\begin{array}{l}-.39 \\
(.72)\end{array}$ & $\begin{array}{c}.73 \\
(1.34)\end{array}$ & $\begin{array}{l}-1.35 \\
(1.11)\end{array}$ & $\begin{array}{l}.33 \\
(.28)\end{array}$ & $\begin{array}{l}.91^{*} \\
(.51)\end{array}$ & $\begin{array}{c}.73 \\
(.49)\end{array}$ \\
\hline $\begin{array}{l}\text { 10-year } \\
\text { Treasury rate }\end{array}$ & $\begin{array}{c}-.84 \\
(1.07)\end{array}$ & $\begin{array}{l}-2.48 \\
(2.00)\end{array}$ & $\begin{array}{c}.45 \\
(1.20)\end{array}$ & $\begin{array}{l}-.08 \\
(.41)\end{array}$ & $\begin{array}{r}-1.06 \\
(.76)\end{array}$ & $\begin{array}{l}-.36 \\
(.55)\end{array}$ \\
\hline $\begin{array}{l}\text { consumer } \\
\text { sentiment }\end{array}$ & $\begin{array}{l}-.15^{*} \\
(.08)\end{array}$ & $\begin{array}{l}.18 \\
(.24)\end{array}$ & $\begin{array}{l}-.09 \\
(.17)\end{array}$ & $\begin{array}{l}.05^{* *} \\
(.03)\end{array}$ & $\begin{array}{l}-.00 \\
(.02)\end{array}$ & $\begin{array}{l}.05 \\
(.03)\end{array}$ \\
\hline $\begin{array}{l}\text { unemployment } \\
\text { rate }\end{array}$ & $\begin{array}{c}1.30 \\
(1.14)\end{array}$ & $\begin{array}{c}2.34 \\
(1.72)\end{array}$ & $\begin{array}{c}-.06 \\
(1.73)\end{array}$ & $\begin{array}{l}.18 \\
(.35)\end{array}$ & $\begin{array}{l}1.03 \\
(.65)\end{array}$ & $\begin{array}{l}.65 \\
(.64)\end{array}$ \\
\hline Q2 dummy & $\begin{array}{c}.94 \\
(2.22)\end{array}$ & $\begin{array}{l}-1.15 \\
(4.52)\end{array}$ & $\begin{array}{c}1.61 \\
(1.81)\end{array}$ & $\begin{array}{l}.22 \\
(.81)\end{array}$ & $\begin{array}{c}-.56 \\
(1.42)\end{array}$ & $\begin{array}{c}.83 \\
(.91)\end{array}$ \\
\hline Q3 dummy & $\begin{array}{c}.10 \\
(2.36)\end{array}$ & $\begin{array}{c}-.26 \\
(4.97)\end{array}$ & $\begin{array}{c}-.59 \\
(1.43)\end{array}$ & $\begin{array}{r}-1.53^{*} \\
(.87)\end{array}$ & $\begin{array}{l}-3.43^{* *} \\
(1.06)\end{array}$ & $\begin{array}{c}.19 \\
(1.01)\end{array}$ \\
\hline Q4 dummy & $\begin{array}{l}-1.01 \\
(2.56)\end{array}$ & $\begin{array}{c}-.28 \\
(4.63)\end{array}$ & $\begin{array}{l}-3.24^{*} \\
(1.72)\end{array}$ & $\begin{array}{r}-1.15 \\
(.78)\end{array}$ & $\begin{array}{c}-2.32^{* *} \\
(.99)\end{array}$ & $\begin{array}{c}.08 \\
(.89)\end{array}$ \\
\hline s.e.e. & 9.21 & 12.64 & 5.03 & 3.12 & 3.23 & 2.88 \\
\hline benchmark s.e.e. & 10.07 & 13.18 & 5.99 & 4.61 & 4.71 & 4.46 \\
\hline adjusted $\mathrm{R}^{2}$ & .16 & .08 & .30 & .54 & .53 & .58 \\
\hline
\end{tabular}

Notes. Newey-West standard errors (computed using a lag truncation parameter of 4) are in parentheses; ${ }^{*}$ and ${ }^{* *}$ denote coefficients that statistically significantly different from zero at the $10 \%$ and $5 \%$ levels. The dependent variable is the advance-to-current revision to real output growth and the acceleration is growth in $t$ minus the weighted average of growth in $t-1, t-2$, and $t-3$, all as currently measured. The benchmark standard error of the estimate is the standard error when only a constant is included on the right-hand-side. 
Table A2 (continued)

Efficiency Tests on Components of GNP or GDP

\begin{tabular}{|c|c|c|c|c|c|c|}
\hline & \multicolumn{3}{|c|}{ Exports } & \multicolumn{3}{|c|}{ Imports } \\
\hline & full & early & late & full & early & late \\
\hline constant & $\begin{array}{l}3.27^{* *} \\
(.48)\end{array}$ & $\begin{array}{l}3.76^{* *} \\
(.67)\end{array}$ & $\begin{array}{l}2.84^{* *} \\
(.40)\end{array}$ & $\begin{array}{l}-.20 \\
(.43)\end{array}$ & $\begin{array}{l}-.32 \\
(.70)\end{array}$ & $\begin{array}{l}-.09 \\
(.45)\end{array}$ \\
\hline $\begin{array}{l}\text { advance growth } \\
\text { rate }\end{array}$ & $\begin{array}{l}.12 \\
(.11)\end{array}$ & $\begin{array}{l}.40^{* *} \\
(.14)\end{array}$ & $\begin{array}{l}-.12^{*} \\
(.07)\end{array}$ & $\begin{array}{l}-.15 \\
(.13)\end{array}$ & $\begin{array}{l}.15 \\
(.13)\end{array}$ & $\begin{array}{l}-.44^{* *} \\
(.12)\end{array}$ \\
\hline $\begin{array}{l}\text { advance } \\
\text { acceleration }\end{array}$ & $\begin{array}{l}-.26^{* *} \\
(.07)\end{array}$ & $\begin{array}{l}-.38^{* *} \\
(.10)\end{array}$ & $\begin{array}{l}-.12^{*} \\
(.06)\end{array}$ & $\begin{array}{l}-.09 \\
(.10)\end{array}$ & $\begin{array}{l}-.13 \\
(.12)\end{array}$ & $\begin{array}{l}-.25^{*} \\
(.14)\end{array}$ \\
\hline $\begin{array}{l}\text { percent change } \\
\text { in } S \& P 500\end{array}$ & $\begin{array}{l}.01 \\
(.02)\end{array}$ & $\begin{array}{l}-.01 \\
(.03)\end{array}$ & $\begin{array}{l}.02 \\
(.03)\end{array}$ & $\begin{array}{l}-.09^{* *} \\
(.02)\end{array}$ & $\begin{array}{l}-.11^{* *} \\
(.03)\end{array}$ & $\begin{array}{l}-.07^{*} \\
(.04)\end{array}$ \\
\hline $\begin{array}{l}\text { 3-month } \\
\text { Treasury rate }\end{array}$ & $\begin{array}{l}.37 \\
(.76)\end{array}$ & $\begin{array}{c}.97 \\
(1.34)\end{array}$ & $\begin{array}{l}-.79 \\
(.88)\end{array}$ & $\begin{array}{l}.68 \\
(.85)\end{array}$ & $\begin{array}{c}.60 \\
(1.40)\end{array}$ & $\begin{array}{c}-.37 \\
(1.17)\end{array}$ \\
\hline $\begin{array}{l}\text { 10-year } \\
\text { Treasury rate }\end{array}$ & $\begin{array}{l}-.71 \\
(.96)\end{array}$ & $\begin{array}{l}-2.63 \\
(1.96)\end{array}$ & $\begin{array}{l}1.33 \\
(.92)\end{array}$ & $\begin{array}{l}-2.17^{* *} \\
(1.09)\end{array}$ & $\begin{array}{l}-2.82 \\
(1.69)\end{array}$ & $\begin{array}{l}-1.00 \\
(1.47)\end{array}$ \\
\hline $\begin{array}{l}\text { consumer } \\
\text { sentiment }\end{array}$ & $\begin{array}{l}-.03 \\
(.07)\end{array}$ & $\begin{array}{l}-.24^{* *} \\
(.11)\end{array}$ & $\begin{array}{l}-.06 \\
(.07)\end{array}$ & $\begin{array}{l}.24^{* *} \\
(.07)\end{array}$ & $\begin{array}{l}.02 \\
(.12)\end{array}$ & $\begin{array}{l}.34 \\
(.10)\end{array}$ \\
\hline $\begin{array}{l}\text { unemployment } \\
\text { rate }\end{array}$ & $\begin{array}{l}1.14 \\
(.92)\end{array}$ & $\begin{array}{l}3.90^{* * *} \\
(1.64)\end{array}$ & $\begin{array}{r}-1.35 \\
(.95)\end{array}$ & $\begin{array}{l}3.53^{* *} \\
(.84)\end{array}$ & $\begin{array}{l}4.55^{* *} \\
(.95)\end{array}$ & $\begin{array}{c}2.28 \\
(1.58)\end{array}$ \\
\hline Q2 dummy & $\begin{array}{c}3.78^{* * *} \\
(1.59)\end{array}$ & $\begin{array}{l}7.71^{\text {*** }} \\
(2.63)\end{array}$ & $\begin{array}{c}1.10 \\
(1.73)\end{array}$ & $\begin{array}{c}2.44 \\
(1.83)\end{array}$ & $\begin{array}{c}2.74 \\
(2.67)\end{array}$ & $\begin{array}{c}5.85^{* *} \\
(2.26)\end{array}$ \\
\hline Q3 dummy & $\begin{array}{l}-2.88^{*} \\
(1.71)\end{array}$ & $\begin{array}{c}-.93 \\
(3.02)\end{array}$ & $\begin{array}{l}-3.96^{* *} \\
(1.85)\end{array}$ & $\begin{array}{l}-1.49 \\
(1.73)\end{array}$ & $\begin{array}{c}2.42 \\
(2.41)\end{array}$ & $\begin{array}{c}-.10 \\
(2.07)\end{array}$ \\
\hline Q4 dummy & $\begin{array}{c}2.30 \\
(1.64)\end{array}$ & $\begin{array}{l}6.15^{* * *} \\
(2.52)\end{array}$ & $\begin{array}{c}.26 \\
(2.01)\end{array}$ & $\begin{array}{c}3.52^{*} \\
(2.00)\end{array}$ & $\begin{array}{l}6.80^{* * *} \\
(2.71)\end{array}$ & $\begin{array}{c}2.13 \\
(2.36)\end{array}$ \\
\hline s.e.e. & 6.33 & 7.32 & 4.89 & 7.93 & 7.59 & 5.73 \\
\hline benchmark s.e.e. & 7.37 & 9.10 & 5.46 & 9.45 & 9.02 & 9.87 \\
\hline adjusted $\mathrm{R}^{2}$ & .26 & .35 & .20 & .30 & .29 & .66 \\
\hline
\end{tabular}

Notes. Newey-West standard errors (computed using a lag truncation parameter of 4) are in parentheses; ${ }^{*}$ and ${ }^{* *}$ denote coefficients that statistically significantly different from zero at the $10 \%$ and $5 \%$ levels. The dependent variable is the advance-to-current revision to real output growth and the acceleration is growth in $t$ minus the weighted average of growth in $t-1, t-2$, and $t-3$, all as currently measured. The benchmark standard error of the estimate is the standard error when only a constant is included on the right-hand-side. 


\section{Figure 1 \\ Distribution of Advance-to-Current Revisions \\ to Real GNP/GDP Growth}

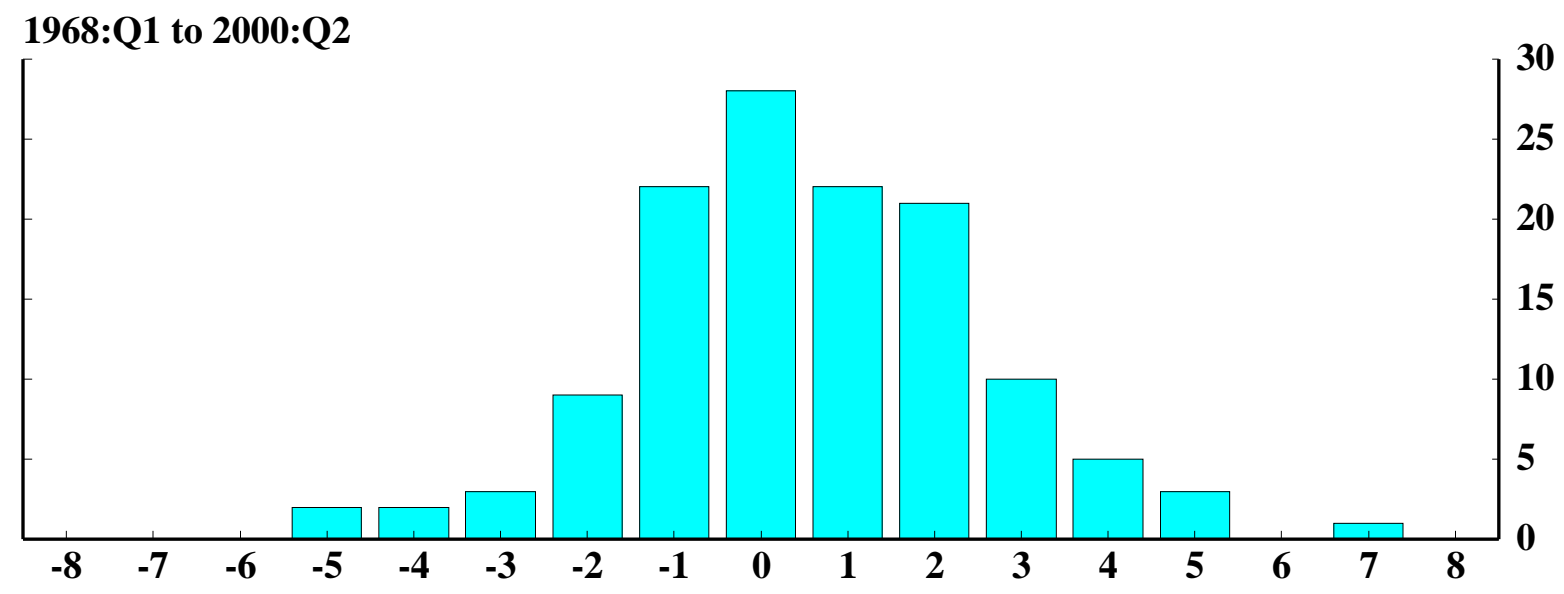

1968:Q1 to 1983:Q4

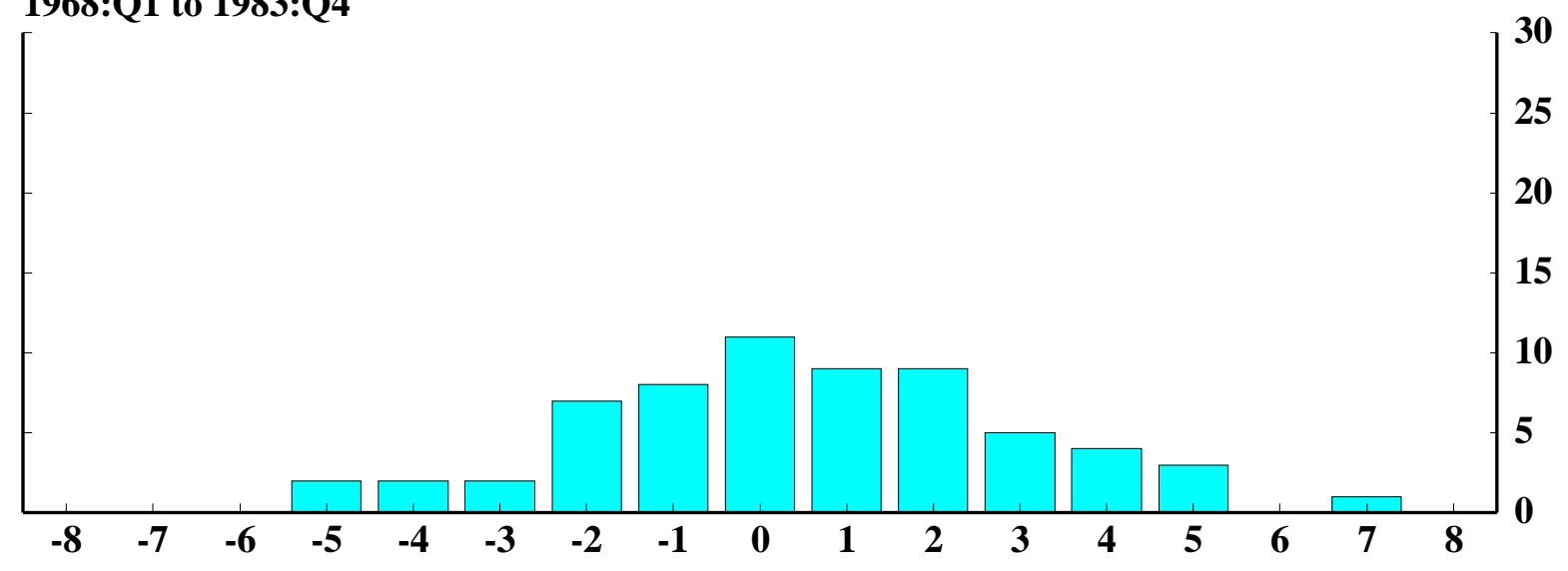

1984:Q1 to 2000:Q2

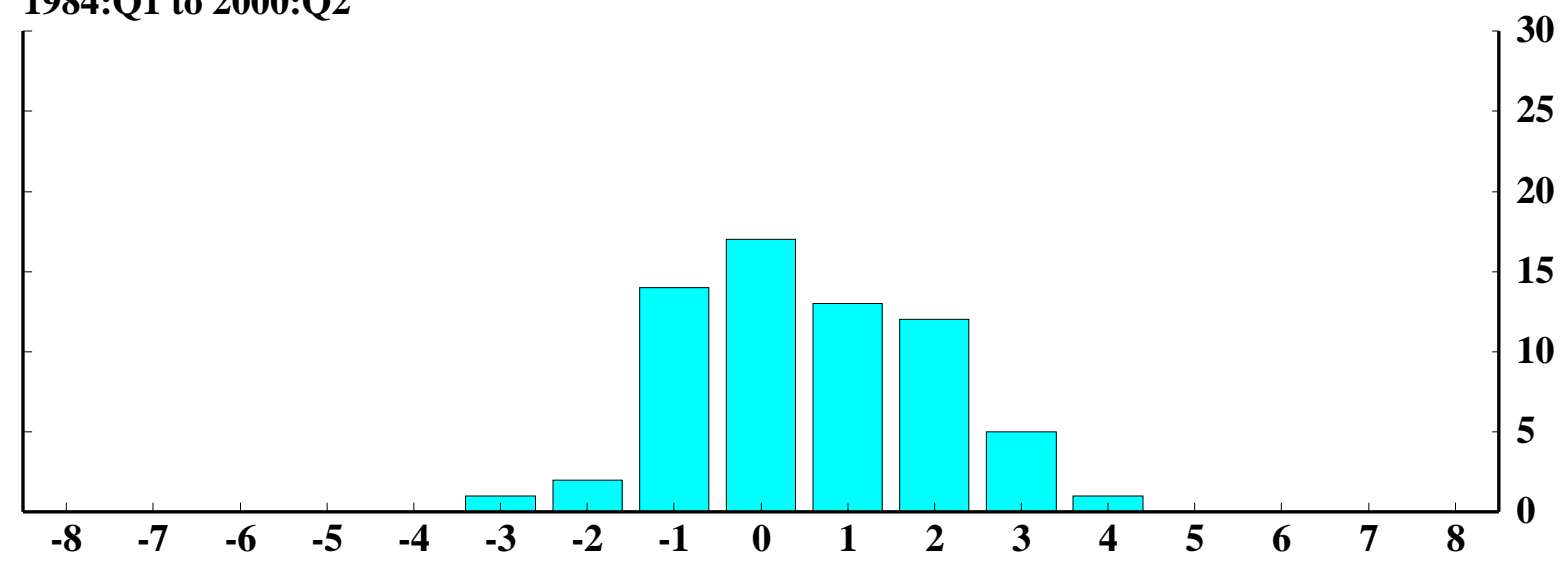

Note. Each bar shows the number of revisions within $1 / 2$ percentage point of the value on the $\mathrm{x}$ axis. 
Figure 2

\section{Revisions to Real GNP/GDP Growth}

Advance Estimate to Following-Quarter Estimate

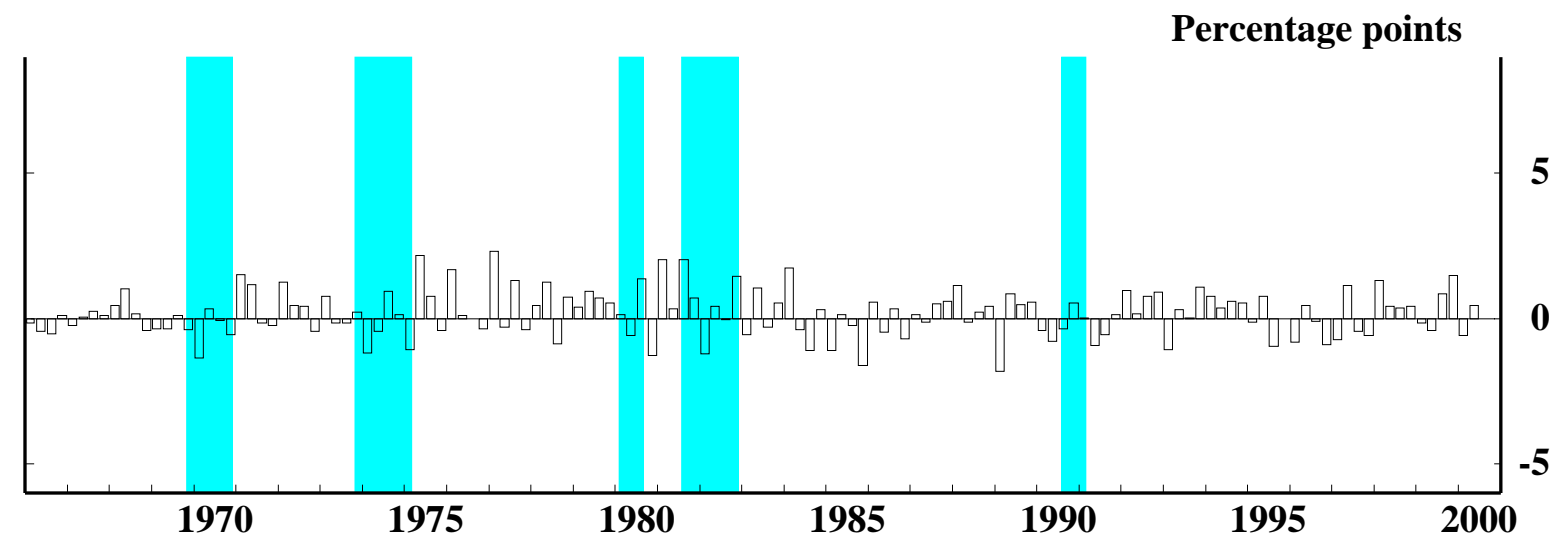

Following-Quarter Estimate to Current Estimate

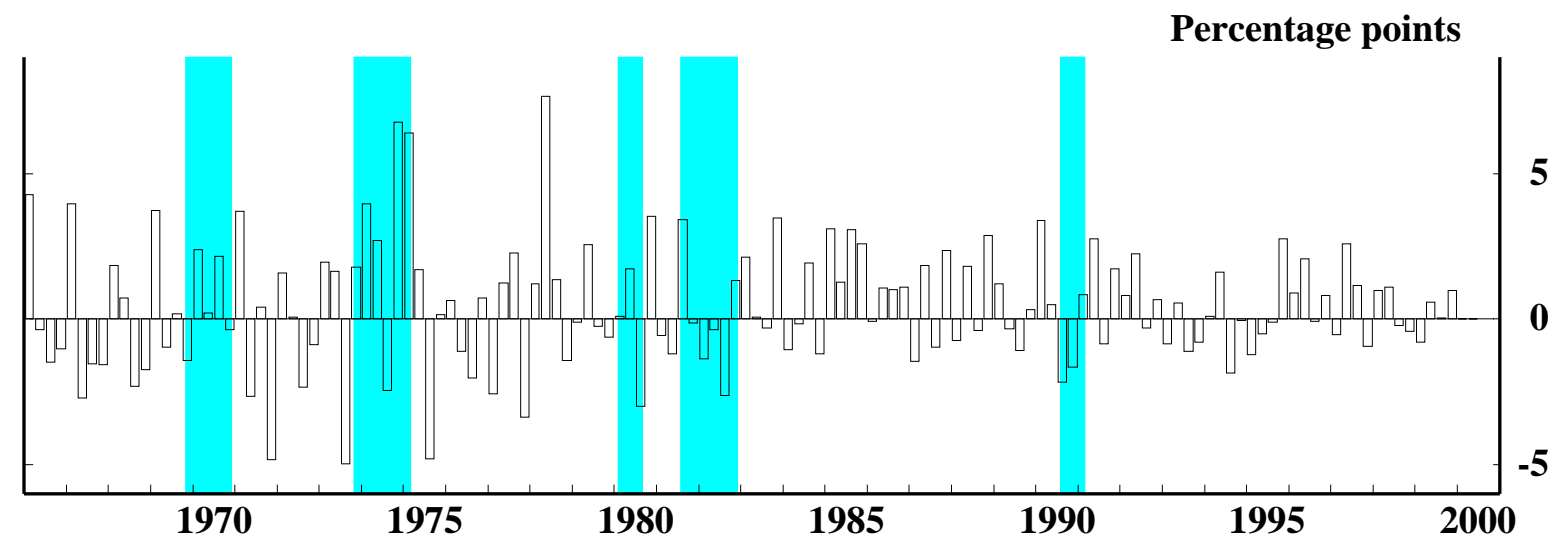

Advance Estimate to Current Estimate

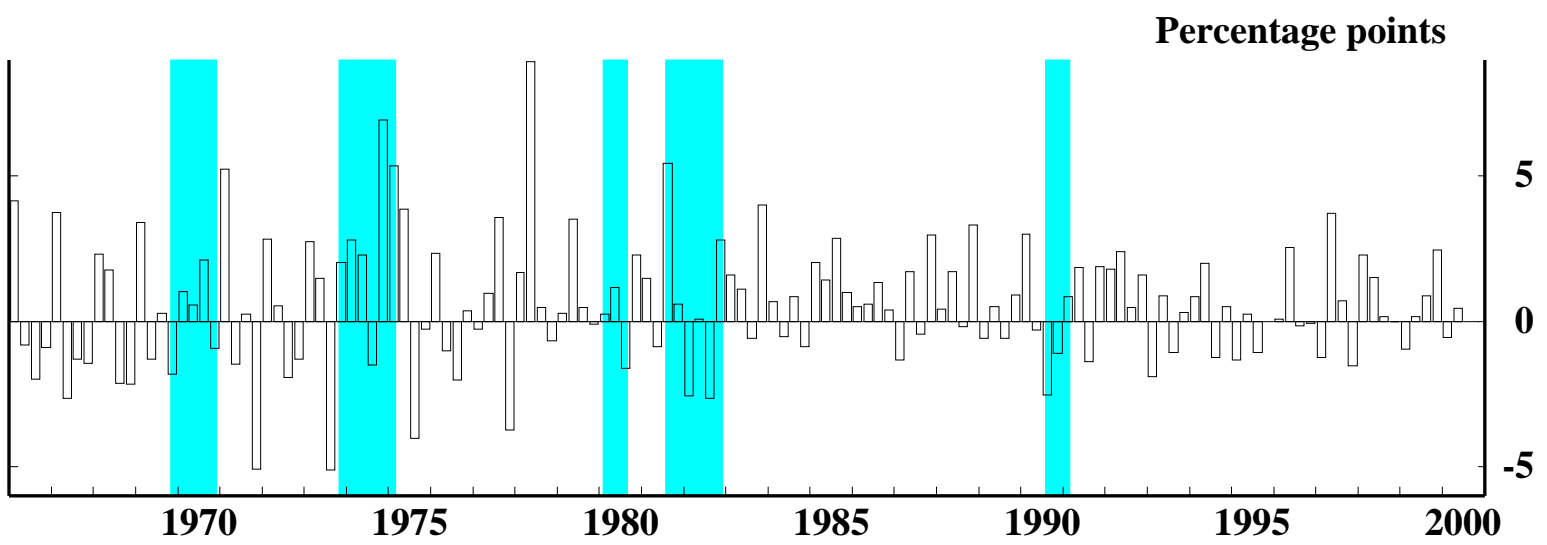


Figure 3

\section{Real GNP/GDP Growth}
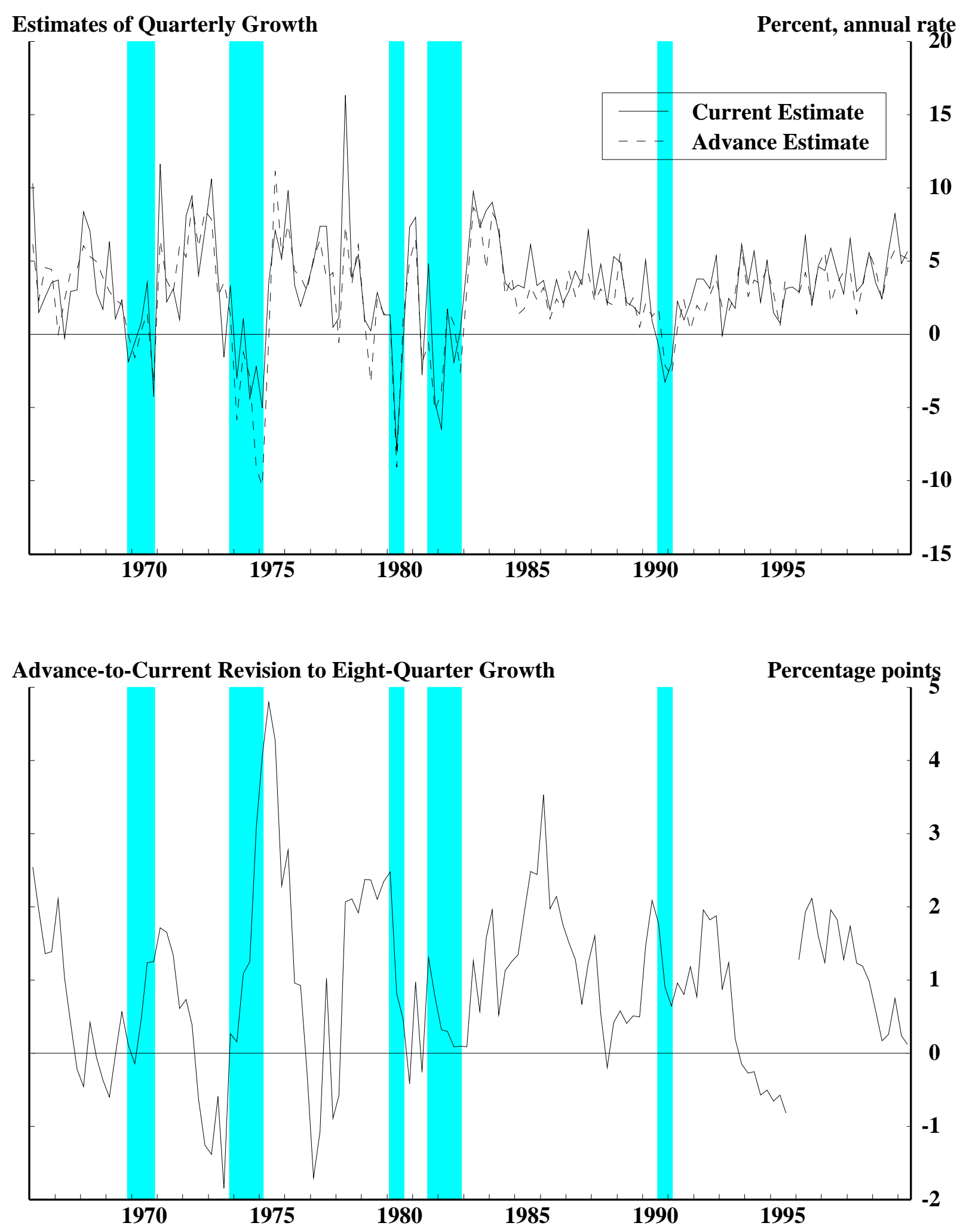
Figure 4

\section{Changes to Estimated Real GDP Growth at Comprehensive Revisions}
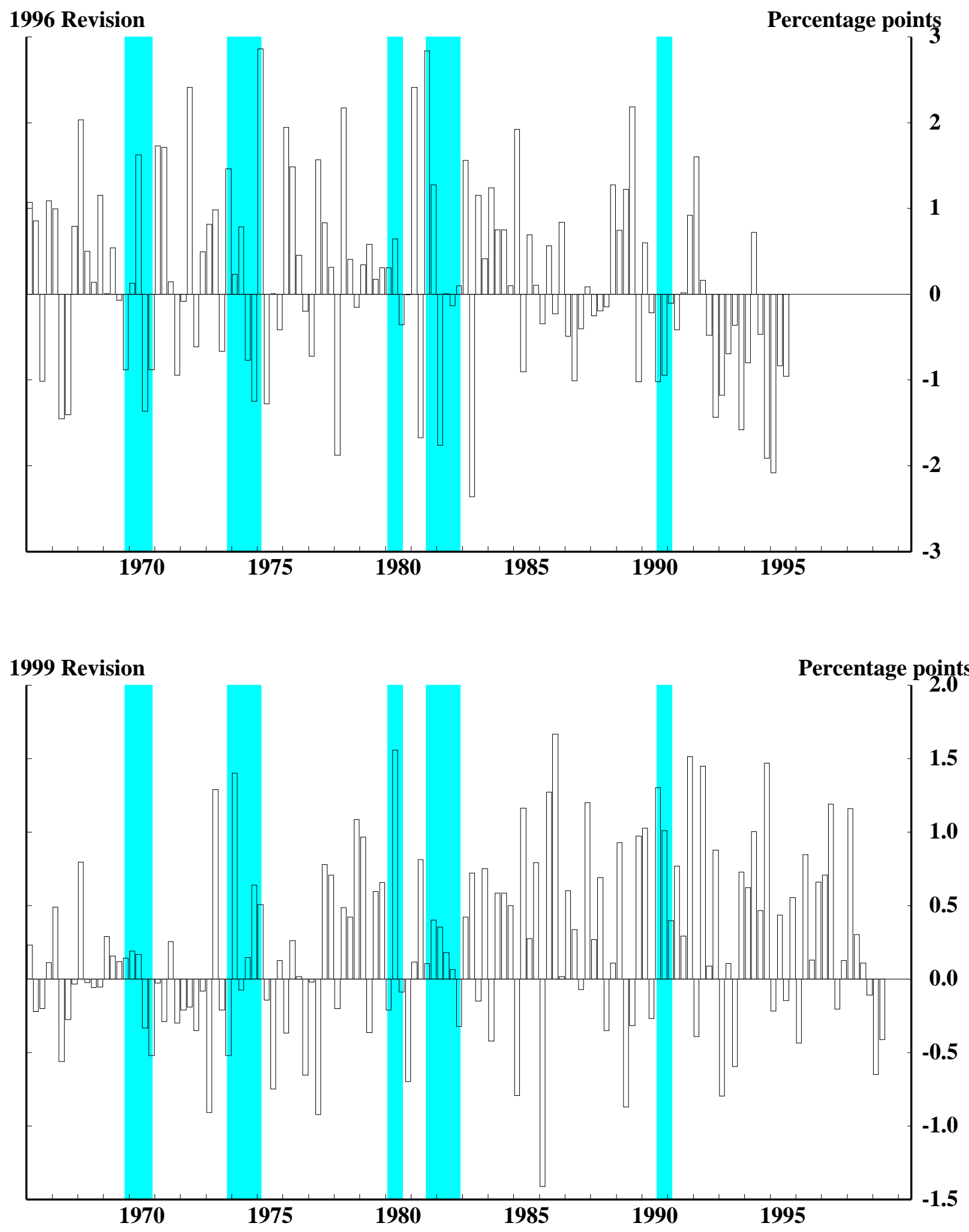


\section{Figure 5}

\section{Real GNP/GDP Growth at Business Cycle Turning Points:}

Evolution of Estimates for Illustrative Quarters

(Each plot shows the estimated growth rate as reported in the NIPAs in each

subsequent quarter. Vertical lines mark dates of comprehensive revisions.)

Beginning of 1973-75 Recession

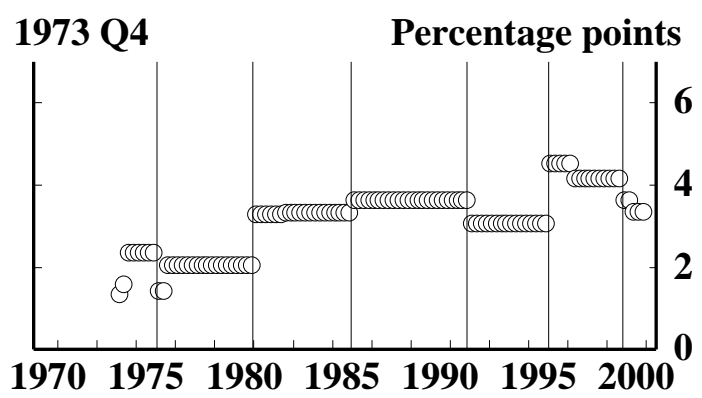

1980 Recession

1980 Q2

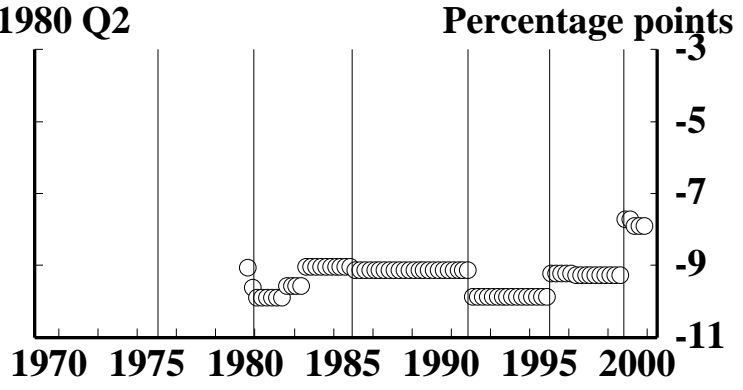

End of 1981-82 Recession

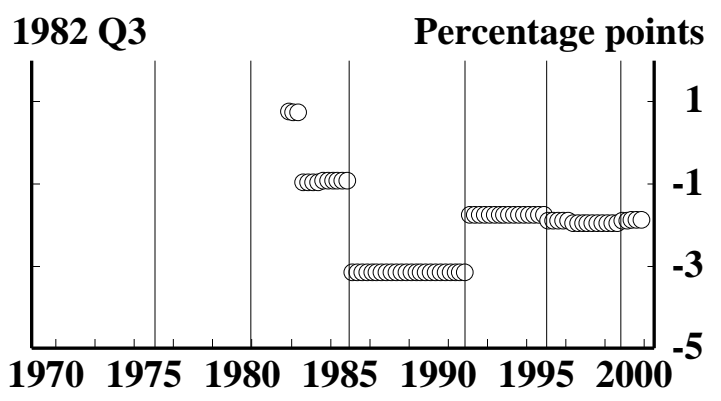

Beginning of 1990-91 Recession

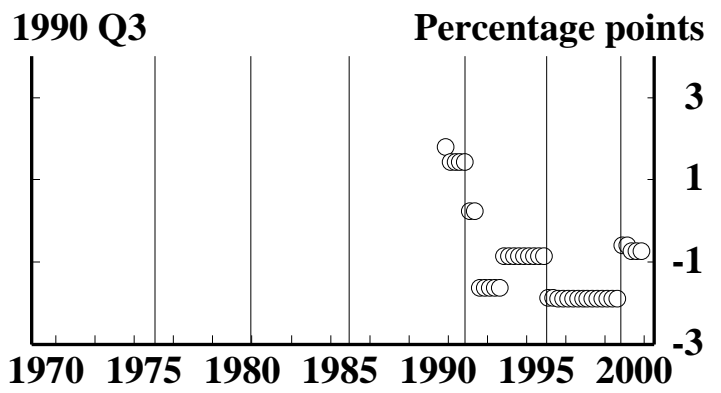

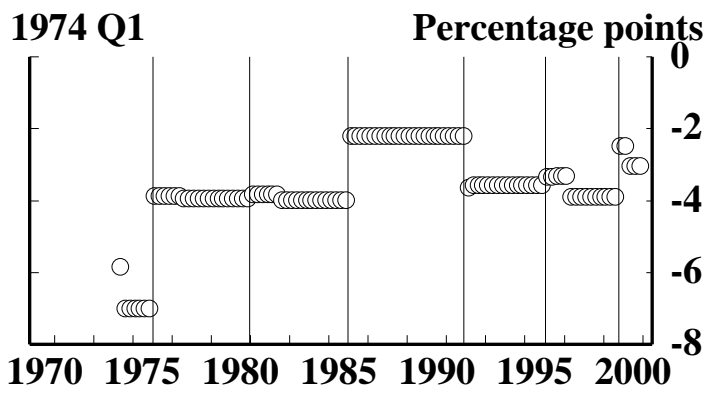
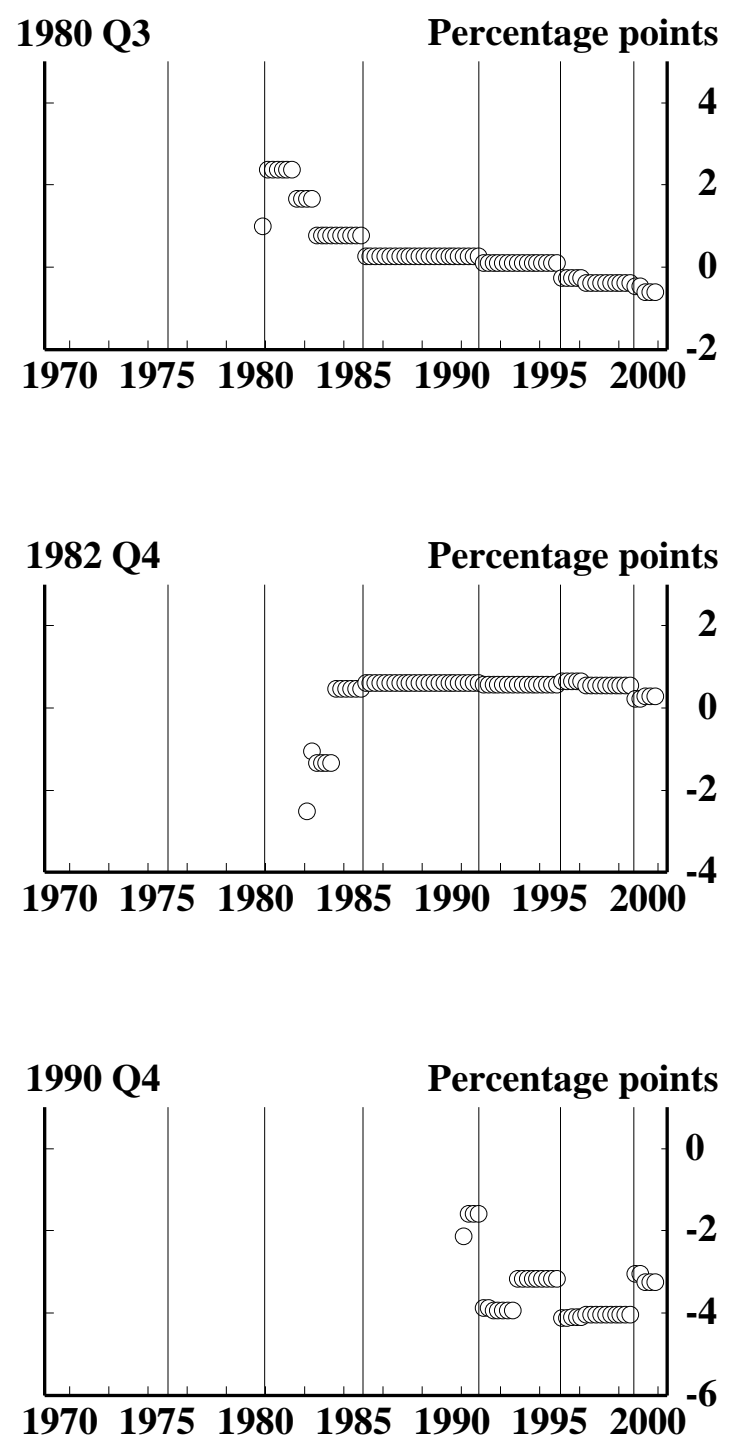